\title{
DEBER DE CONFIDENCIALIDAD Y SECRETO PROFESIONAL DEL ABOGADO*
}

\author{
The Attorney's Duty of Confidentiality and the Attorney Client Privilege
}

Antonio Bascuñán Rodríguez.*

\begin{abstract}
Resumen: El presente trabajo aborda el análisis de la nueva regulación sobre el deber de confidencialidad y secreto profesional del abogado consagrada por el nuevo Código de Ética Profesional del abogado, aprobado por acuerdo del Consejo General que entró en vigor el $1^{\circ}$ de Agosto de 2011. En este texto normativo se introduce una regulación novedosa y extensa en materia de secreto profesional, dedicándole 15 disposiciones distribuidas en cuatro apartados diversos. Así, en el Título preliminar (art. 7) se enuncia el deber de confidencialidad como principio general; en el art. 42 se establece el deber de uso de la información del cliente en su interés prohibiendo su aprovechamiento en beneficio del abogado o de terceros sin consentimiento del cliente; el grueso de la nueva regulación se concentra en la relación del abogado con su cliente; y, por último, los arts. 110 y 111 regulan el deber de confidencialidad debida entre abogados de contrapartes. De este modo, el Código de Ética distingue entre el deber de confidencialidad y los deberes relativos al uso de información confidencial, al tiempo que diferencia entre la confidencialidad hacia el cliente y la debida al abogado de la contraparte. Todo ello con importantes consecuencias prácticas puestas de relieve en este estudio.
\end{abstract}

Palabras clave: deber de confidencialidad - secreto profesional del abogado - Código de Ética Profesional - uso información confidencial - relación abogado-cliente confidencialidad abogados contraparte.

\begin{abstract}
This paper addresses the analysis of new regulation on the duty of confidentiality and legal privilege enshrined in the new Code of Professional Ethics Counsel, approved by resolution of the General Council which came into force on 1 August 2011. This regulatory text introduces new and extensive regulation regarding confidentiality by dedicating 15 provisions organized in four sections. Thus, in the Preliminary Title (Article 7) states the duty of confidentiality as a general principle; in art. 42 establishes a duty to use customer information in their interest by prohibiting their use for the benefit of counsel or third parties without customer consent; the bulk of the new regulation focuses on the relationship of the lawyer to his client, and, finally, the arts. 110 and 111 regulate the duty of confidentiality owed between counterparties lawyers. Thus, the Code of Ethics distinguishes between the duty of confidentiality and duties relating to

\footnotetext{
* Versión revisada de la exposición efectuada por el autor el martes 24 de enero de 2012 en el Colegio de Abogados, en el marco del Programa para capacitación de Jueces Éticos. El autor agradece a Pablo Fuenzalida Cifuentes, coordinador de la Comisión de Ética del Colegio de Abogados (2007-2011), y a Ana María Carbonne Herrera, Secretaria de la Presidencia del Colegio de Abogados, por su inestimable ayuda en la recopilación de los trabajos preparatorios del nuevo Código de Ética Profesional del Abogado.

** Abogado. Profesor de Derecho. Universidad Adolfo Ibáñez.

Correo electrónico: a.bascunan@uai.cl
} 
Bascuñán - Deber de confidencialidad y secreto profesional del abogado

the use of confidential information, the time difference between confidentiality to the client and due to opposing counsel. All with important practical implications highlighted in this paper.

Keywords: duty of confidentiality - legal privilege - Code of Professional Ethics Counsel use of confidential information - relationship lawyer-client - confidentiality to the opposing counsel.

\section{Presentación}

El propósito de estas páginas es comentar la nueva regulación sobre deber de confidencialidad y secreto profesional del abogado consagrada por el nuevo Código de Ética Profesional del Abogado, aprobado por acuerdo del Consejo General (en adelante, "el Consejo") adoptado en su $5^{a}$ sesión ordinaria del año 2011, de 4 de abril, y cuya vigencia comenzó el $1^{\circ}$ de agosto de 2011 (en adelante "CEP-2011"). Este acuerdo revocó y sustituyó el acuerdo del Consejo del 14 de mayo de 1984, por el cual se adoptó como regla para el ejercicio de la jurisdicción disciplinaria en su calidad de Asociación Gremial al Código de Ética Profesional que había sido aprobado por el Colegio de Abogados el 28 de octubre de 1948 y que comenzó a regir el $1^{\circ}$ de enero de 1949 (en adelante "CEP-1948).

El CEP-2011 introduce una regulación novedosa en materia de secreto profesional. Es también una regulación extensa. En lugar de los tres artículos que el CEP-1948 destinaba a esta materia -arts. 10, 11 y 12-, el CEP-2011 le dedica 15

\footnotetext{
1 El análisis del ámbito de aplicación y fuerza vinculante del CEP-2011 excede el margen de este comentario. Resumidamente, mi posición al respecto es la siguiente: (i) el D.L. 3621 (D.O. 07.02.1981) prohibió a los colegios profesionales ejercer la jurisdicción disciplinaria que sus respectivas leyes orgánicas les conferían y transfirió esa jurisdicción a los tribunales de justicia; (ii) el CEP-1948 es un complemento normativo del art. $4^{\circ}$ del D.L. 3621 (D.O. 07.02.1981); en consecuencia, debe ser aplicado por los tribunales de justicia; (iii) el Colegio de Abogados es una asociación gremial (D.L. 2757, D.O. 04.07.1979), que ejerce jurisdicción disciplinaria sobre sus afiliados dentro del margen de la potestad normativa y de policía correccional que los arts. 553 y 554 del Código Civil otorgan a las corporaciones de derecho privado; (iv) el Colegio de Abogados adoptó en 1984 el CEP-1948 como norma para el ejercicio de su jurisdicción disciplinaria; (v) la Ley de Reforma Constitucional 20.050 (D.O. de 26 de agosto de 2005) reconoció la validez de la jurisdicción disciplinaria ejercida por los colegios profesionales exclusivamente sobre sus afiliados; (vi) el Colegio de Abogados ejerce, en consecuencia, jurisdicción disciplinaria constitucionalmente reconocida pero en su calidad legal de asociación gremial; (vii) el Colegio de Abogados adoptó en 2011 un nuevo CEP como norma para el ejercicio de su jurisdicción disciplinaria; (viii) la validez jurídica de las normas del CEP-2011 que establecen deberes más extensos o más rigurosos que las normas del CEP-1948 no es problemática; la validez de las normas que establecen deberes menos extensos o menos rigurosos que las normas del CEP-2011 no puede descansar en su consideración como autoexoneración corporativa, sino que exige entenderlas como reformulación de las exigencias deontológicas a la luz de la evolución del derecho constitucional y legal chileno; (ix) en tal calidad, todas las normas del CEP-2011 constituyen una base de prueba de la lex artis de la profesión jurídica chilena y en esa medida un elemento relevante para la interpretación del CEP1948, aunque no sean jurídicamente vinculantes para los abogados que no se encuentren afiliados al Colegio.
} 
REJ - Revista de Estudios de la Justicia - No 15 - Año 2011

disposiciones, ubicadas en cuatro apartados diversos. El siguiente cuadro comparativo ilustra esta diferencia:

\begin{tabular}{|c|c|c|}
\hline Materia & CEP-2011 & CEP-1948 \\
\hline Principio general & Art. $7^{\circ}$ & Art. 10 \\
\hline $\begin{array}{c}\text { Deberes relativos al uso de } \\
\text { la información }\end{array}$ & Art. 42 11 \\
\hline $\begin{array}{c}\text { Deber de confidencialidad } \\
\text { para con el cliente }\end{array}$ & Arts. 46 a 64 & Arts. 10, 11, 12 \\
\hline $\begin{array}{c}\text { Deber de confidencialidad } \\
\text { para con el abogado de la } \\
\text { contraparte }\end{array}$ & Arts. 110-111 & Art. 11 \\
\hline
\end{tabular}

Como se puede apreciar, el grueso de la nueva regulación se concentra en los arts. 46 a 64 del CEP-2011, que corresponden al título iv de su primera sección, dedicada a la relación del abogado con su cliente.

$\mathrm{El}$ art. $7^{\circ}$ enuncia el deber de confidencialidad como principio general en el contexto del título preliminar.

El art. 42 establece el deber de uso de la información del cliente en su interés, prohibiendo su aprovechamiento en beneficio del abogado o terceros, sin el consentimiento del cliente. A pesar de que se refiere al manejo de la información confidencial, es un deber fiduciario distinto de la confidencialidad ${ }^{2}$. Por esa razón se lo ubica en el título iii de la primera sección, relativo a los deberes del abogado en la relación profesional.

Finalmente, los arts. 110 y 111 regulan la confidencialidad debida entre abogados de contrapartes. Dado que no se trata de un deber fiduciario surgido de la relación profesional abogado-cliente, se lo distingue sistemáticamente de las otras reglas sobre confidencialidad, y se lo trata en el título i de la sección cuarta, a propósito de las relaciones entre abogados con relaciones fiduciarias respecto de clientes distintos.

\footnotetext{
${ }^{2}$ Esto implica que el campo propio de aplicación de la prohibición de aprovechamiento del art. 42 se encuentra en los modos de uso de la información que no supongan revelación de la misma. Si el uso implicara revelación, entonces también queda cubierto bajo el deber de confidencialidad (art. 46) y todas sus consecuencias normativas. La apreciación de infracciones múltiples por una misma acción no está excluida.
} 
Bascuñán - Deber de confidencialidad y secreto profesional del abogado

Como se verá, estas dos decisiones sistemáticas del CEP-2011 -distinguir entre el deber de confidencialidad y los deberes relativos al uso de información confidencial, distinguir entre confidencialidad debida al cliente y confidencialidad debida al abogado de la contraparte- tienen importantes consecuencias prácticas.

La fijación de las nuevas normas en los artículos del CEP-2011 se produjo en una etapa tardía de su discusión y aprobación por el Consejo. Durante los años 2008 y 2009 las nuevas normas fueron discutidas y aprobadas como reglas agrupadas en seis párrafos temáticos, comprendiendo cada párrafo una secuencia de reglas relativas al tema, lo que se expresaba en su numeración (por ejemplo, el $\int 1$ comprendía las reglas $1.1,1.2$ y 1.3). Los $\int S 1,3,4$ y 5 originales fueron mantenidos en el CEP-2011 como $\int \mathbb{S} 1,2,3$ y 4 del título iv de la sección primera. El $\int 2$ original fue eliminado, transfiriéndose una de sus reglas al nuevo $\ 1$ del título iv y la otra al título i de la sección primera. El $\int 6$ original también fue eliminado, transfiriéndose sus reglas a los arts. 5 y 6 de una propuesta sobre integridad en el trato de abogados, y luego a los arts. 110 y 111 CPE-2011.

La elaboración de las nuevas reglas sobre deber de confidencialidad y secreto profesional se sujetó a las siguientes etapas: ${ }^{3}$

(i) El grupo de trabajo sobre secreto profesional, constituido por convocatoria del Consejo 2007-2009 y coordinado por el abogado Álvaro Anríquez Novoa, presentó el 13 de junio de 2008 ante la Comisión de Ética del Colegio de Abogados, constituida por el Consejo para llevar adelante la elaboración del nuevo Código de Ética Profesional, un documento que contenía un levantamiento de casos relevantes para elaborar una propuesta de regulación; el documento fue expuesto y discutido en la Comisión en sesión del 18 de junio de 2008.

(ii) El grupo de trabajo presentó ante la Comisión de Ética una propuesta preliminar de regulación (en adelante "PP") compuesta de cinco párrafos, sin inclusión de la confidencialidad entre abogados de contrapartes, en sesión del 27 de agosto de 2008.

(iii) La PP revisada por el grupo de trabajo fue presentada ante el Consejo 2007-2009 en sus sesiones de 8 y 29 de septiembre de 2008. Las reglas fueron aprobadas con algunas modificaciones y publicadas en la página web del Colegio.

\footnotetext{
${ }^{3}$ La historia de su elaboración se explica en la sección I.1 del documento titulado "Propuesta de nuevas reglas para la ética profesional del abogado, fundamentación y comentarios", presentado al Consejo el 27 de marzo de 2009 e incorporado como anexo en su $8^{a}$ sesión ordinaria del año 2009, en 22 de junio de 2009. El documento tiene tres partes: (i) fundamentación, (ii) propuesta de regulación, (iii) comentarios, a las que en adelante se referirá como "PD-i", "PD-iii" y "PD-iii", respectivamente. La PITA se encuentra en el texto titulado Integridad en el trato entre colegas, documento de la Comisión de Ética y Códigos de Buenas Prácticas del Colegio de Abogados de Chile A.G., 26 de noviembre de 2010, 13 páginas. Este documento no fue incorporado en actas.
} 
REJ - Revista de Estudios de la Justicia - No 15 - Año 2011

(iv) El grupo de trabajo presentó al Consejo 2009-2011 su propuesta definitiva de regulación (en adelante "PD") el 27 de marzo de 2009. Esta propuesta fue discutida y aprobada por el Consejo en nueve sesiones durante el año 2009.

(v) El grupo de trabajo sobre integridad en el trato entre abogados, constituido por el Consejo 2009-2011, discutió ante la Comisión de Ética su propuesta de regulación (en adelante, "PITA"), inclusiva de normas sobre confidencialidad entre abogados de contrapartes en sesión de 15 de diciembre de 2010.

(vi) El Consejo 2009-2011 constituyó una Comisión Revisora que reunió sistemáticamente en un solo cuerpo normativo todas las reglas aprobadas a proposición de los distintos grupos de trabajo, más la PITA, agregando un título preliminar. El texto elaborado por la Comisión Revisora fue finalmente aprobado por el Consejo por acuerdo adoptado en su $5^{\text {a }}$ sesión ordinaria del año 2011, de 4 de abril.

El texto aprobado por el Consejo como nueva regulación del deber de confidencialidad y el secreto profesional corresponde en lo esencial a la PD (Arts. $7^{\circ}, 42,46$ a 64) y a la PITA (Arts. 110 y 111), con algunas modificaciones de redacción introducidas por la Comisión Revisora. Para facilitar la consulta de los trabajos preparatorios, el siguiente cuadro ofrece una correlación entre las reglas de la PD/PITA y los artículos del CEP-2011, indicando la respectiva sesión del Consejo (de la Comisión de Ética, en el caso de la PITA) en las cuales se discutieron las reglas.

\begin{tabular}{|c|c|c|c|}
\hline Artículos CEP-2011 & Reglas PD/PITA & $\begin{array}{c}\mathbf{N}^{\circ} \text { acta } \\
\text { Consejo/Comisión } \\
\text { de Ética }\end{array}$ & Fecha sesión \\
\hline $7^{\circ}, 46,47,48$ & $1.1,1.2,1.3$ & $8 / 2009$ & 22 junio \\
\hline $48,(22), 49,50,51,52$ & $1.3,2.1,2.2,3.1,3.2$ & $9 / 2009$ & 13 julio \\
\hline $52,53,54$ & 3.3 & $10 / 2009$ & 27 julio \\
\hline 54,55 & 4.2 y 4.3 & $12 / 2009$ & 31 agosto \\
\hline $55,56,57,58,59$ & $4.3,4.4,4.5,4.6$ & $13 / 2009$ & 14 septiembre \\
\hline 60 & 5.1 y 5.2 & $14 / 2009$ & 28 septiembre \\
\hline 60,61 & 5.1 y 5.2 & $15 / 2009$ & 19 octubre \\
\hline $62,63,64$ & $5.3,5.4,6$ & $17 / 2009$ & 30 noviembre \\
\hline 110 & 6.1 y 6.2 & $18 / 2009$ & 14 diciembre \\
\hline 110,111 & 5,6 PITA & $12 / 2010$ C. de E. & 15 diciembre \\
\hline 110,111 & --- & $5 / 2011$ & 4 abril \\
\hline CEP-2011 íntegro & & & \\
\hline
\end{tabular}

A continuación procederé a analizar brevemente el contenido de la nueva regulación sobre confidencialidad y secreto profesional del abogado, siguiendo el orden del CEP-2011, en la siguiente secuencia: 
el principio general $\left(\right.$ art. $\left.7^{\circ}\right)$;

el deber de confidencialidad (arts. 46 a 49)

la revelación consentida por el cliente (arts. 50 a 52)

la revelación no consentida por el cliente (arts. 53 a 59)

el secreto profesional (arts. 60 a 64)

la confidencialidad entre abogados de contrapartes (arts. 110-111).

El principio general

Artículo $7^{\circ}$. Confidencialidad y secreto profesional. El abogado debe estricta confidencialidad a su cliente. En cumplimiento de su obligación debe exigir que se le reconozca el derecho al secreto profesional con que la ley lo ampara. La confidencialidad debida se extiende a toda la información relativa a los asuntos del cliente que el abogado ha conocido en el ejercicio de su profesión, en los términos establecidos por las reglas del Título IV de la Sección Primera de este Código.

$\mathrm{El}$ art. $7^{\circ}$, junto con las demás disposiciones del título preliminar, fue redactado por la Comisión Revisora. Su origen se encuentra en las reglas 1.1 y 5.2 PD. La disposición cumple tres funciones:

(i) Enuncia la confidencialidad debida por el abogado a su cliente -nótese: no al abogado de la contraparte- como un principio general del CEP-2011 y se remite a las normas del título iv de la sección primera para su regulación detallada.

El concepto de cliente y la definición del inicio y término de la relación profesional se encuentran regulados por los arts. 14 a 20 CEP-2011.

(ii) Explicita la distinción conceptual entre el deber ético de confidencialidad y el derecho legal al secreto profesional, que constituye la principal innovación sistemática de la nueva regulación. Tal como la disposición lo expresa, la ética profesional impone al abogado un deber de confidencialidad para con su cliente y un deber de hacer valer el reconocimiento legal de su deber ético de confidencialidad como un derecho (en rigor, una exención) frente a eventuales deberes de declarar o informar. El ejercicio de este derecho legal no es facultativo para el abogado, pues la exención es consecuencia del reconocimiento legal de la preponderancia del deber de confidencialidad del abogado respecto de los deberes de declarar o informar en colisión.

Esta distinción conceptual pone de manifiesto la necesidad de explicitar el fundamento del deber de confidencialidad, para que pueda ser considerado como un deber preponderante frente a deberes de revelar en colisión con él. En lo esencial, se puede decir que hay tres fundamentos atendibles: 
(a) el interés individual del cliente, que corresponde al carácter fiduciario de su relación con el abogado;

(b) el interés corporativo en la integridad de la profesión, que hace de su reserva y discreción un rasgo constitutivo de esa integridad;

(c) el interés colectivo en el adecuado desempeño de un rol institucional por el abogado dentro del sistema jurídico y en particular dentro de la administración de justicia, lo que requiere un flujo desinhibido de información por parte del cliente; el deber de confidencialidad es así una compensación normativa del incremento del riesgo de difusión de la información contraria a los intereses del cliente; dicha compensación tiene por finalidad desinhibir el flujo de información requerido para que el abogado desempeñe adecuadamente su rol institucional.

En términos generales, a la ética profesional del abogado le basta con considerar el interés individual del cliente en una relación fiduciaria con su abogado para imponer a éste el deber de confidencialidad. En cierto sentido, se puede considerar además que este interés es coincidente con el interés corporativo en la integridad de la profesión, entendida como confianza general en la calidad de agentes fiduciarios de los abogados. Este es, sin duda, el fundamento del deber de confidencialidad que tiene presente el artículo $7^{\circ}$ y en general los arts. 46 a 64 .

Sin embargo, el interés corporativo puede adquirir relevancia propia como fundamento de los deberes éticos del abogado cuando pretende justificar el deber de confidencialidad incluso contra la voluntad o el interés del cliente. Atisbos de estas situaciones se encuentran en la segunda oración del art. 51 y en el art. 110.

El interés colectivo constituye el umbral diferenciador entre el deber ético de confidencialidad y el deber jurídico de guardar reserva que se expresa en la institución del secreto profesional. La diferencia entre ambas instituciones no es directamente relevante para la mayor parte de las cuestiones que puede presentar la aplicación del CEP-2011 en el contexto de la adjudicación de responsabilidad disciplinaria por infracciones a la ética profesional. Ella es sin embargo esencial para tener una posición bien fundamentada acerca de la preponderancia del deber de confidencialidad frente a eventuales situaciones de colisión con deberes de declarar o informar. Más que una cuestión propia de la jurisdicción ética, se trata de una cuestión recurrente en los amparos profesionales que brinda el Colegio frente a actos de atropello al ejercicio de la profesión concretados en intrusiones o coacciones a declarar o informar. Sobre eso se volverá a propósito del $\ 4$ del título iv de la sección primera (infra, 5).

(iii) Finalmente, el art. $7^{\circ}$ consagra una regla fundamental de la nueva regulación en su tercera oración: "la confidencialidad debida se extiende a toda la información relativa a los asuntos del cliente que el abogado ha conocido en el 
Bascuñán - Deber de confidencialidad y secreto profesional del abogado

ejercicio de su profesión”. Esta es una definición amplísima del ámbito protegido por el deber de confidencialidad.

Como es bien sabido, conforme al art. 10 CEP-1948 el secreto profesional cubría tres ámbitos de información: "las confidencias hechas por terceros al abogado, en razón de su ministerio", "las [confidencias] que sean consecuencia de pláticas para realizar una transacción que fracasó" y "las confidencias de los colegas". En los tres casos se trataba de confidencias hechas al abogado por terceras personas. El término empleado por el CEP-1948 corresponde al uso más restringido de los textos legales que reconocen el secreto profesional, el artículo $360 \mathrm{~N}^{\circ} 1$ del Código de Procedimiento Civil, que exime a los abogados de declarar "sobre hechos que se les hayan comunicado confidencialmente con ocasión de su (...) profesión”. En su sentido natural y obvio, la expresión excluye del secreto profesional la información producida por el abogado para el cliente, así como la información recibida de terceros sin carácter de comunicación confidencial. Si bien es cierto que el Colegio sostuvo en su pronunciamiento a lo largo del siglo xx una concepción amplia del ámbito cubierto por el secreto, al mismo tiempo declaró en su jurisprudencia disciplinaria que el secreto profesional impedía revelar "hechos confidenciales" en los juicios de honorarios contra el cliente. ${ }^{4}$ Como es obvio, si por "hechos confidenciales" hubiera que entender toda información relativa al cliente, como lo obliga ahora el art. $7^{\circ}$ CEP-2011, bajo el CEP-1948 habría sido imposible un cobro judicial de honorarios conforme a la ética profesional.

La nueva regulación se desembaraza de todos los problemas de calificación de la información como protegida por el deber de confidencialidad atendiendo a la fuente de la información, al modo concreto de su adquisición o producción por el abogado y a su contenido específico. Toda información relativa al cliente se encuentra ahora bajo deber de confidencialidad. Esto requiere una regla que autorice el uso de la información en interés del cliente bajo la figura del consentimiento presunto, lo cual es otra novedad de la regulación del CEP-2011.

\footnotetext{
${ }_{4}^{4}$ Acuerdo de 6 de octubre de 1950, en sesión N9/1950, p. 7, según Pardo Valencia, Fanny: Ética y Derecho de la Abogacía en Chile, Santiago: Editorial Jurídica de Chile, 1969 (reproducción fotostática para integrantes del Consejo del Colegio de Abogados, Santiago, 2007), p. 78.
} 
REJ - Revista de Estudios de la Justicia - No 15 - Año 2011

\section{2}

El deber de confidencialidad

Título IV: Deber de confidencialidad

\section{$\int 1$. Deber de confidencialidad para con el cliente}

Artículo 46. Deberes que comprende el deber de confidencialidad. El deber de confidencialidad comprende:

a) Probibición de revelación. El abogado debe abstenerse de revelar la información cubierta por su deber de confidencialidad, así como de entregar, exhibir o facilitar el acceso a los soportes materiales, electrónicos o de cualquier otro tipo que contengan dicha información y que se encuentran bajo su custodia.

b) Deberes de cuidado. El abogado debe adoptar medidas razonables para que las condiciones en las que recibe, obtiene, mantiene o revela información sujeta a deber de confidencialidad sean tales que cautelen el carácter confidencial de esa información; y

c) Deber de cuidado respecto de acciones de colaboradores. El abogado debe adoptar medidas razonables para que la confidencialidad debida al cliente sea mantenida por quienes colaboran con él.

Artículo 47. Duración indefinida. El deber de confidencialidad no se extingue por el término de la relación profesional, la muerte del cliente, ni el transcurso del tiempo.

Artículo 48. Deber de revelar información por abogado que desempeña una función pública. El abogado que en el ejercicio de una función pública está sujeto a un deber legal de revelar o entregar la información de que dispone en razón de esa función no puede excusarse de cumplir ese deber a pretexto de su calidad profesional de abogado.

Artículo 49. Prioridad del deber de confidencialidad. El deber de confidencialidad para con un cliente prevalece sobre cualquier deber fiduciario para con otro cliente.

Los artículos 46, 47 y 48 corresponden, respectivamente, a las reglas 1.1, 1.2 y 1.3 PD. El artículo 49 corresponde a las regla 2.1 PD.

El art. 46 desarrolla el contenido del deber de confidencialidad, precisando con mucho mayor detalle el viejo concepto de "guardar el secreto profesional" (art. 10 CEP-1948).

En primer lugar -art. 46(a) - están las prohibiciones ( $=$ deberes de abstención) de revelar la información poseída y de hacer accesibles a terceros los 
Bascuñán - Deber de confidencialidad y secreto profesional del abogado

soportes que la contienen y que se encuentran bajo su custodia. Aunque esta segunda prohibición tematiza explícitamente comportamientos activos, debe entenderse que la tolerancia del acceso por un tercero a esa información (i.e., la omisión de impedirlo) también viola la confidencialidad debida. Eso es consecuencia del deber de custodia de dichos soportes.

En segundo término - art. 46(b) - están los deberes de cuidado relativos a las circunstancias en que se da el flujo de la información, ya sea hacia el abogado ("recibe, obtiene") o desde el abogado ("revela"), o su mantención en soportes bajo custodia del abogado, de modo que no se divulgue a terceros por el hecho de su flujo o custodia. La "revelación" de información por el abogado en cuya ocasión se requiere observar un deber de cuidado no es, por supuesto, aquella revelación que infringe el art. 46(a). La regla no tiene por objeto ofrecer una medida de la gravedad de la indiscreción del abogado. Se trata de los casos de transmisión de la información bajo confidencialidad desde el abogado hacia otra persona, o sea, de una cadena de insiders secundarios: el abogado debe adoptar precauciones para que con ocasión de esa transmisión la información confidencial no sea accesible para los outsiders.

Finalmente -art. 46(c)-, está la responsabilidad del abogado por los hechos de terceros colaboradores suyos. Se trata de terceros que por su función son incorporados en el círculo de poseedores o custodios de la información confidencial, pero que por el hecho de no ser abogados no están sujetos a un deber ético de confidencialidad que compense normativamente el incremento de riesgo para el interés del cliente creado por su incorporación en ese círculo. No se trata, por lo tanto de outsiders que vencen las precauciones adoptadas por el abogado con ocasión de su custodia de los soportes o de los procedimientos de recepción, producción o transmisión de información. Esos casos están cubiertos por el art. 46-(b). Se trata aquí de insiders secundarios sucesivos, respecto de los cuales el abogado debe adoptar medidas contractuales o laborales que compensen el incremento de riesgo antedicho.

Las reglas del art. 46(b) y 46(c) definen el deber del abogado como un imperativo de "adoptar medidas razonables". Esa terminología tiene por finalidad hacer explícito que se trata de una obligación de medios y no de resultados. ${ }^{5}$

El art. 46 no define quien se entiende como "cliente" del abogado. Esa materia se encuentra regulada por los arts. 15, 16 y 20. La referencia al abogado obligado para con el cliente debe entenderse extensiva de todos los abogados de un mismo estudio (art. 11). Naturalmente, varios abogados pueden tener el mismo

\footnotetext{
5 Las reglas 1.1(ii) y 1.1 (iii) PP utilizaban la expresión "medidas adecuadas". El cambio de redacción en las reglas de la PD se explica por la razón expresada en el texto (sesión N 15/2008, de 8 de septiembre).
} 
cliente. ${ }^{6}$ Es importante tener presente que el deber de confidencialidad y el deber de invocar el secreto profesional se tienen para con el cliente potencial, irrestrictamente (art. 20).

El art. 47 mantiene la regla del art. 10 CEP-1948, que disponía que el secreto profesional "perdura en lo absoluto, aun después de que les haya dejado de prestar sus servicios". Debe observarse, no obstante, que en la nueva regulación existe una excepción a esta regla, regulada por el art. 63-(a) CEP-2011, que permite revelar información de un cliente fallecido para impedir la condena de un inocente.

El art. 48 es una regla curiosa, particularmente en cuanto a su ubicación en este párrafo. Su finalidad es explicitar que la información que un abogado conoce en el ejercicio de una función pública y que está sujeta a deberes de divulgación, ya sea por el principio general de transparencia o por obligaciones específicas de entrega a personas calificadas, no se transforma en información confidencial bajo la ética profesional por el mero hecho de detentar el funcionario la calidad profesional de abogado. ${ }^{7}$ No es por lo tanto un caso de colisión de deberes que la ética profesional resuelva autorizando la revelación. ${ }^{8}$ Estos casos se encuentran

6 La regla 1.2 PP preveía como confidencialidad debida entre abogados dos casos que consideraba analogables a la confidencialidad debida al cliente: (i) cuando es información relativa a un cliente de su estudio; (ii) cuando es información recibida en razón del requerimiento de servicios profesionales. La regla 1.2(i) se hizo innecesaria bajo el art. 11 CEP-2011. La regla 1.2(ii) fue considerada innecesaria por obvia (cfr. PD-iii, regla 1.1).

${ }^{7}$ La pregunta de si es posible la prestación de servicios profesionales de abogado (art. 15) en el desempeño de un cargo o función pública depende de la respuesta a la pregunta más general de si la regulación -legal y ética- de la profesión de abogado considera compatibles el ejercicio de la profesión y la subordinación jerárquica, laboral o administrativa. Si se responde afirmativamente a esta segunda pregunta, entonces se abre la posibilidad de que un abogado se encuentre sujeto al deber de confidencialidad respecto de información que ha conocido con ocasión de la prestación de servicios profesionales y el desempeño del cargo simultáneos. Pero el abogado-funcionario público que invoque el secreto profesional tiene que justificar su aplicabilidad al caso, más allá de su mera calidad profesional de abogado. En Carrasco contra Álvarez, un caso en que el Fiscal de una Municipalidad rehusó complementar la información entregada para una auditoría interna a la fiscalía comunal, la Corte de Apelaciones de San Miguel decidió que "ninguna persona o autoridad (incluida, obviamente, la Municipalidad en que labora el actor), posee facultades para exigir a un abogado, aun cuando sea funcionario de su dependencia, que entregue o revele información confidencial que ha recibido u obtenido de sus representantes o de terceros en el ejercicio de su profesión" (sentencia de 12 de agosto de 1998, recaída sobre recurso de protección, Rol № 135-98, considerando $9^{\circ}$ ). Al parecer, se trataba de información referida a la representación judicial de personas residentes en la comuna; la sentencia no es precisa en la descripción de los hechos, porque la Corte de San Miguel no advirtió los problemas abstractos de calificación involucrados y porque en concreto declaró que había que respetar la prerrogativa de calificación del abogado. La sentencia de la Corte de San Miguel fue revocada por la Corte Suprema, debido a que los hechos no eran constitutivos de afectación de derechos constitucionales (sentencia de 15 de septiembre de 1998 Rol N²2928-98).

${ }^{8}$ En Consejo de Defensa del Estado contra Consejo de la Transparencia, la Corte de Apelaciones de Santiago consideró que las reglas sobre deber de confidencialidad y secreto profesional, incluidas las del CPE-2011, "priman" sobre el art. 48 CPE-2011 (sentencia de 13.03.2012, sobre recurso de 
Bascuñán - Deber de confidencialidad y secreto profesional del abogado

regulados en el $\ 3$. Se trata de un caso de fraude a la ley por funcionario público bajo pretexto de un deber ético, por lo que la disposición podría haberse ubicado en la sección quinta del CEP-2011.

$\mathrm{El}$ art. 49 es el remanente del $\ 2 \mathrm{PD}$, correspondiendo a su regla 2.1. ${ }^{9} \mathrm{La}$ disposición establece una regla de preponderancia absoluta para el deber de confidencialidad en caso de colisión de deberes para con distintos clientes. La redacción de la disposición sufrió variaciones durante su tramitación. La regla 2.1 PP establecía lo siguiente: "El deber de confidencialidad para con un cliente prevalece sobre el deber de información para con otro cliente". El Consejo consideró que esa prioridad no podía ser absoluta, ${ }^{10}$ por lo que la regla $2.1 \mathrm{PD}$ ofreció la siguiente redacción: "El deber de confidencialidad para con un cliente prevalece sobre cualquier deber fiduciario para con otro cliente, salvo cuando la revelación de información sujeta a deber de confidencialidad produzca en el primero un perjuicio irrelevante $y$, además, manifiestamente menor que el provecho que la revelación ocasiona al segundo". Se trataba de una regla de prioridad prima facie de la confidencialidad, reversible bajo una consideración combinada de bagatela y preponderancia del interés en conflicto con la confidencialidad debida. Posteriormente, sin embargo, el Consejo aprobó una regla de prioridad absoluta, dejando en lo demás la cuestión entregada a la regulación de los conflictos de intereses (sección segunda del CEP-2011). ${ }^{11}$ Esa regla única del párrafo 2 fue finalmente convertida en el art. 49.

La transferencia de la regulación de esta colisión específica de deberes a las reglas sobre conflicto de intereses, anticipadas por el principio general del art. 22 ("criterio de prevención"), fue sin duda una medida acertada. Sin embargo, no todos los casos que son relevantes como colisión de deberes bajo el art. 49 quedan cubiertos por las reglas sobre conflictos de intereses.

El art. 85 resuelve de modo congruente con los arts. 22 y 49 el caso de conflicto de intereses entre el deber de confidencialidad para con un cliente previo, actual o pasado, y los deberes fiduciarios para con un cliente potencial posterior. La inhabilitación para intervenir en el asunto del cliente potencial posterior expresa

ilegalidad, Rol N 5746-2011, cons. $7^{\circ}$ ). En sus propios términos, la aserción carece de sentido; ella debe entenderse como una negación de que los abogados del Consejo de Defensa del Estado sean funcionarios sujetos a un deber de transparencia, en el sentido del art. 48 CPE-2011, en lo que se refiere a la información que conocen con ocasión de la defensa judicial de los intereses del Fisco. El Consejo de la Transparencia concedió esa apreciación, pero limitándola a la existencia de un litigio pendiente; en su opinión, el término del litigio por sentencia ejecutoriada relevaba a los abogados del Consejo de Defensa del Estado de su deber de reserva. Con toda razón, la Corte rechazó ese argumento: semejante limitación temporal es incompatible con la institución del secreto profesional.

9 La regla 2.2 PP/PD, que correspondía en parte al art. 11 CEP-1948, fue generalizada y se encuentra en el art. 22 CEP-2011.

${ }^{10}$ Acta $\mathrm{N}^{\circ} 15 / 2008$, sesión de 8 de septiembre.

${ }_{11}$ Acta $\mathrm{N}^{\circ}$ 9/2009, sesión de 13 de julio. 
la prioridad del deber de confidencialidad para con el cliente previo. Dado lo dispuesto por el art. 20, el cliente potencial pasado cuyo interés de confidencialidad pudiera entrar en colisión con los intereses del nuevo cliente potencial queda comprendido por la regla del art. 85 .

Tratándose de un conflicto de intereses sobreviniente, o sea, un conflicto que surge cuando el cliente posterior no es potencial sino actual, el art. 86 establece la solución de dispensa o inhabilitación respecto de todos los clientes cuyos intereses se encuentran en conflicto. La solución es compatible con la prioridad de la confidencialidad. Dado lo dispuesto por el art. 47, el cliente pasado queda comprendido por la regla del art. 86 en lo que se refiere a su interés de confidencialidad. ${ }^{12}$

Pero el caso más problemático para los integrantes del Consejo 2007-2009 y 2009-2011 era el del cliente potencial que en las conversaciones preliminares transmite al abogado información confidencial cuya posesión lo pone en conflicto con sus deberes fiduciarios para con un cliente previo y actual. Este caso no está cubierto por los arts. 85 y 86, porque las reglas sobre conflictos de intereses no son directamente aplicables al cliente potencial, conforme a lo dispuesto por el art. 20. Dado que el caso debe resolverse conforme al art. 42 y a las reglas sobre confidencialidad, se plantea la pregunta de si la posesión de esa información inhabilita al abogado para continuar prestando sus servicios al cliente previo-actual en virtud de la regla de prioridad absoluta del art. 49. La aplicación de esas reglas lleva a las siguientes conclusiones:

(i) La prohibición de revelación de la información confidencial recibida del cliente potencial prima sobre los deberes fiduciarios para con el cliente previoactual. Eso es consecuencia de lo establecido por los arts. 20 y 49. Esto implica que el abogado no podrá cumplir respecto del cliente previo-actual con el deber de información establecido por el art. 28.

(ii) El aprovechamiento de la información confidencial recibida del cliente potencial en la prestación del servicio profesional al cliente previo-actual se encuentra prohibido por el art. 42, en tanto aprovechamiento en beneficio de tercero, aplicable al caso en virtud del art. 20. Esto implica que el abogado no podrá cumplir con su deber de prestar los servicios profesionales con empeño y eficacia, establecido por los artículos $4^{\circ}$ y 25 , respecto del cliente previo-actual.

(iii) El abogado puede salir de cualquiera de los dos conflictos de intereses obteniendo el consentimiento expreso del cliente potencial para revelar la

\footnotetext{
${ }^{12}$ En mi opinión, el cliente pasado también queda comprendido en lo que se refiere a su interés en la abstención de uso de la información confidencial por el abogado en beneficio de sí mismo o de un tercero. El principio del art. 47 debe ser extendido al deber del art. 42. De otro modo, se inhibiría el derecho del cliente a poner término a la relación profesional.
} 
Bascuñán - Deber de confidencialidad y secreto profesional del abogado

información al cliente previo-actual y/o para aprovecharla en su beneficio (arts. 42, 50 y 51$)$.

(iv) Si no cuenta con el consentimiento expreso del cliente potencial, el abogado también puede salir del dilema poniendo término a su relación profesional con el cliente previo-actual, mediante renuncia conforme al art. 18-(c), basado en la prevención de una colisión de deberes.

El resultado a que se llega con las cuatro consideraciones anteriores es semejante al que se arribaría si se considerara que el art. 86 es aplicable al caso. Esto implica una equiparación del cliente potencial al cliente en sentido estricto, que sin embargo el CEP no hace. Entre el abogado y el cliente potencial no se ha constituido la relación profesional, por lo que aquél no tiene respecto de éste la plenitud de sus deberes fiduciarios sino sólo los mencionados por el art. 20. Esta diferencia puede evaluarse de dos modos. Por una parte, se la podría menospreciar considerando que si bien el art. 20 sólo hace aplicable algunos deberes al cliente potencial, todos los deberes aplicables a él tienen el mismo alcance, intensidad y rigor que si se trata de un cliente en sentido estricto. Desde este punto de vista, que el resultado de aplicar el art. 42 y las reglas sobre confidencialidad coincida con lo que sería el resultado de aplicar el art. 86 confirma la coherencia del CEP-2011. Por otra parte, se la podría valorar significativamente, observando que el hecho de que el art. 86 no sea aplicable al caso en cuestión constituye más bien un refutador potencial de la conclusión a la que se llega aplicando rigurosamente el art. 42 y las reglas sobre confidencialidad. Desde este segundo punto de vista, cabría explorar una posible solución alternativa a la colisión de deberes, atendiendo el menor peso específico que tiene la posición de cliente potencial. Eso no es posible con el deber de confidencialidad para con el cliente potencial, atendida la regla de prioridad absoluta del art. 49 y la exigencia de texto expreso para justificar la revelación no consentida que se encuentra en el art. 54(g). Pero es posible plantearlo en relación con la prohibición de aprovechamiento establecida por el art. 42, porque los arts. 49 y $54(\mathrm{~g})$ no le son aplicables conforme a sus propios términos. Partiendo de esta premisa, el intérprete del CEP-2011 tendría las siguientes alternativas: o bien (a) extiende por analogía la reglas de los arts. 49 y 54(g) a la prohibición del aprovechamiento del art. 42, o bien (b) acepta la posibilidad de una justificación del aprovechamiento de la información confidencial por colisión de deberes, bajo una consideración razonable de ponderación. Si acepta esta posibilidad, ${ }^{13}$ habría un

\footnotetext{
${ }^{13}$ La extensión del principio del art. 49 y la exigencia del art. 54(g) al deber del art. 42 no tiene la misma necesidad práctica que la extensión del principio del art. 47 a ese deber (supra, nota 12). Además, las razones para reforzar la protección del interés del cliente en evitar la revelación de la información confidencial se explica porque la revelación implica una lesión total e irreversible del interés del cliente. En cambio, el uso de la información en beneficio de otro cliente puede serle inocuo, cuando se trata de modalidades de uso que no implican revelación. En todo caso, la aceptación de esta posibilidad debe enfrentar otro obstáculo: el que representa la declaración del propio art. 42, en el sentido de que el abogado sólo puede usar la información confidencial de su cliente para otra finalidad que el interés del cliente en "los casos en que la ley o este Código lo
} 
margen para que el abogado continúe prestando sus servicios al cliente previoactual, satisfaciendo los estándares de los arts. $4^{\circ}$ y 25: el margen dado por la ausencia de perjuicio para el cliente potencial.

Aparte de esta arriesgada apertura a una solución de colisión de deberes no reconocida expresamente por el CEP-2011, otra manera de resolver el conflicto de intereses podría ser que el abogado comunique al cliente previo-actual, sin comprometer la confidencialidad debida al cliente potencial, que posee información de su interés que sin embargo no puede revelarle ni aprovecharla en todo o en parte (según lo que se estime atendiendo a la consideración anterior) para la prestación del servicio, con el fin de que el cliente previo-actual decida si poner término a la relación profesional o aceptar la continuación de la misma a pesar de esa reserva y restricción. La aceptabilidad de esta solución depende de lo que se decida en general respecto de si es válida la liberación parcial al abogado de los deberes impuestos por los arts. $4^{\circ}, 25$ y 28 sin contar con toda la información pertinente pero estando advertido de esa circunstancia. Aun si se aceptara la validez de esa renuncia, es claro que ella sólo puede darse dentro del margen en que no acarre al cliente un perjuicio que sería evitable por la prestación de servicios de otro abogado que no se encuentre inhibido por la posesión de esa información. El rebasamiento de ese margen infringiría el deber de lealtad del abogado para con su cliente $\left(\operatorname{art.} 3^{\circ}\right)$.

Es importante observar que las soluciones anteriores son combinables para todos los modos de aprovechamiento sin revelación de la información del cliente potencial en beneficio del cliente previo-actual.

La incertidumbre que rodea las soluciones alternativas a la inhibición pura y simple del abogado para seguir prestando sus servicios al cliente previo-actual demuestra que nunca se insistirá lo suficiente en el cuidado que debe tener un abogado al momento de atender la consulta de un cliente potencial.

Por último, debe tenerse siempre presente que la calidad de cliente potencial supone que la consulta efectuada al abogado haya expresado una intención seria de obtener sus servicios profesionales (art. 20). La solicitud de servicios efectuada de mala fe, con el fin de inhabilitar al abogado, no constituye consulta para efectos de la calificación del solicitante como cliente potencial.

obligan o facultan a darle otro destino". Habría que sostener que el sentido de esta regla es menos estricto que el sentido de la regla del art. 54(g). 
Bascuñán - Deber de confidencialidad y secreto profesional del abogado

3

La revelación consentida por el cliente

\section{$\int 2$. Revelación consentida por el cliente}

Artículo 50. Consentimiento del cliente. No falta a su deber el abogado que revela información sujeta a confidencialidad con el consentimiento expreso o presunto de su cliente.

Artículo 51. Consentimiento expreso. El consentimiento expreso debe ser prestado con la debida ilustración por parte del abogado que lo solicita. La autorización del cliente no obliga al abogado a revelar información sujeta a confidencialidad. El abogado informado por terceros de haber sido relevado por su cliente debe cerciorarse, en forma previa a la revelación, de que esa liberación es efectiva. En cualquier momento el cliente puede revocar su consentimiento.

Artículo 52. Consentimiento presunto. Se presume que el cliente consiente la revelación que es conveniente para la exitosa prestación de los servicios profesionales del abogado a ese cliente, a menos que éste haya dispuesto algo diferente. En caso de duda, el abogado debe confidencialidad.

A diferencia del CEP-1948, que regulaba el secreto profesional sin referencia alguna a la voluntad del cliente, el CEP-2011 atiende al consentimiento del cliente como causa que excluye la responsabilidad ética del abogado por la revelación de la información confidencial, distinguiendo entre consentimiento expreso y consentimiento presunto. Los arts. 50, 51 y 52 reproducen en lo esencial las reglas 3.1, 3.2 y 3.3 PD.

El art. 50 establece el principio de que el consentimiento del cliente libera al abogado del deber de confidencialidad y distingue sus formas expresa $y$ presunta.

La procedencia del consentimiento expreso como causa de cancelación del deber de confidencialidad es obvia cuando se considera que el deber de confidencialidad es un deber fiduciario, es decir, que su fundamento se encuentra en el interés del cliente. Esa obviedad puede explicar la ausencia de su regulación en el CEP-1948. Pero también puede explicarla la suposición de que el CEP-1948 consideraba que el fundamento del deber de confidencialidad se encuentra en un interés colectivo, como es la consideración de la integridad de la profesión. Si ese fuera el caso, el cliente no podría consentir la revelación de la información cubierta por el secreto profesional. $^{14}$ El CEP-2011 parte inequívocamente de la

\footnotetext{
${ }^{14}$ No está de más observar que el Código Penal sistematiza a la revelación de secretos del cliente por parte del abogado (art. 231) y a la revelación de secretos por parte de un profesional (art. 247
} 
REJ - Revista de Estudios de la Justicia - No 15 - Año 2011

consideración del interés del cliente como fundamento del deber de confidencialidad.

Asumiendo que el fundamento del deber de confidencialidad se encuentra en el interés del cliente, la procedencia del consentimiento presunto depende en principio de la conjunción entre la imposibilidad de obtener el consentimiento expreso del cliente y la impostergabilidad de la decisión de revelar información confidencial. Pero además depende la extensión del ámbito cubierto por la confidencialidad. Para una concepción estrecha de ese ámbito, restringida a las "confidencias" en sentido estricto, la idea de una revelación presuntivamente consentida carece de plausibilidad, salvo casos excepcionalísimos. Eso puede explicar la ausencia de su regulación en el CEP-1948. En cambio, bajo una concepción amplia del ámbito cubierto por la confidencialidad, como la que establece el art. $7^{\circ}$ CEP-2011, la operación rutinaria de la institución del consentimiento presunto resulta indispensable para que el deber de confidencialidad no inhiba la prestación de los servicios profesionales del abogado.

La institución del consentimiento expreso como liberación de deberes éticos no es exclusiva del deber de confidencialidad. El CEP-2011 lo contempla también a propósito de la prohibición de aprovechamiento de la información confidencial (art. 42), la prohibición de desempeño como árbitro o mediador (art. 67), la representación conjunta (art. 84), la dispensa del conflicto de intereses (arts. 86 y 90) y la intervención ante medios de comunicación (art. 101). ${ }^{15}$ El principio que gobierna todos estos casos se encuentra expresado en el art. $3^{\circ}$, que ordena al abogado respetar la autonomía del cliente.

El consentimiento presunto del cliente, en cambio sólo se contempla en una situación además de la revelación de información confidencial, cual es, la intervención ante medios de comunicación (art. 101). Los principios que gobiernan el consentimiento presunto son la lealtad al cliente y el respeto a su autonomía (art. $\left.3^{\circ}\right)$.

El art. 51 regula el consentimiento expreso del cliente. La disposición utiliza una expresión algo cursi - "debida ilustración"- para explicitar que la validez del consentimiento expreso del cliente se sujeta a los criterios de la institución del consentimiento informado. ${ }^{16}$ La regulación más detallada de esta

inciso segundo) como delitos cometidos por funcionarios públicos en el ejercicio de sus cargos (título v del libro segundo), es decir, en principio como atentados contra un interés colectivo.

15 Además, el art. 10 se refiere al consentimiento del cliente en otorgar al abogado la facultad de disponer de sus derechos del cliente, y los arts. 17 y 100 se refieren al consentimiento del abogado en la asunción de la relación profesional y la confidencialidad debida al abogado de la contraparte.

16 La terminología del CEP-2011 no es enteramente uniforme. La mayoría de las disposiciones que se refieren a la liberación de los deberes éticos del abogado por el cliente utilizan la expresión "consentimiento expreso e informado" (arts. 67, 84, 90). Los arts. 15 y 101 utilizan la expresión "consentimiento informado"; los arts. 42 y 117, la expresión "consentimiento expreso"; el art. 86, la sola expresión "consentir". La diferencia de redacción no altera la identidad de sentido: en todos 
Bascuñán - Deber de confidencialidad y secreto profesional del abogado

institución en el CEP-2011 se encuentra en el art. 90, relativo a la dispensa en caso de conflicto de intereses. Las formalidades exigidas por el art. 90 -escrituración, constancia escrita de las reglas del CEP de cuyo cumplimiento de libera al abogado- no constituyen un requisito general de validez del consentimiento informado. Sí, en cambio, sus exigencias materiales adecuadamente generalizadas: el abogado debe exponer ante el cliente los riesgos y desventajas que pueden derivarse de la revelación de la información confidencial. El cliente debe poder comprender cabalmente el sentido, alcance y consecuencias previsibles de la revelación que autoriza, y, desde luego, manifestar su voluntad con plena capacidad y sin coacción.

$\mathrm{El}$ art. 51 establece además tres reglas:

(i) El consentimiento del cliente autoriza al abogado para revelar la información, pero no lo obliga a efectuarla (segunda oración). Esta es una concesión a la idea de que el fundamento del deber de confidencialidad se encuentra en la consideración a la integridad de la profesión. En tal calidad, constituye una excepción justificada al deber de obrar según las instrucciones del cliente (art. 28). El ejercicio de esta excepción no es, sin embargo, enteramente discrecional. Las instrucciones del cliente que se encuentran avaladas por una consideración razonable de proporcionalidad como la que justifica el consentimiento presunto no pueden ser desatendidas por el abogado bajo pretexto de integridad profesional.

(ii) El abogado informado de la existencia de un consentimiento expreso por parte del cliente, que no le consta, debe cerciorarse de ese hecho (tercera oración). La importancia de este deber en el caso de una citación del abogado a declarar en juicio hace que el CEP-2011 reproduzca la regla en su art. 61.

(iii) El consentimiento del cliente es esencialmente revocable (oración final).

Los arts. 15 y 117 regulan casos especiales de consentimiento expreso del cliente a la revelación de información profesional por el abogado. ${ }^{17}$ A ellos les son aplicables todos los requisitos del consentimiento informado.

los casos en que el CEP atribuye al consentimiento del cliente el efecto de relevar al abogado de un deber ético, y no admite explícitamente su carácter presunto, se trata de un consentimiento expreso e informado. La aplicabilidad de esta institución a otros casos de asunción consensual de obligaciones regulados por el CEP (arts. 17 y 100) es una cuestión de interpretación sistemática.

17 Art. 15 (inciso segundo): "No es cliente quien remunera los servicios profesionales que benefician a un tercero. Sin embargo, el abogado, con el consentimiento informado de su cliente, puede mantener también informado al tercero que remunera sus servicios respecto del desarrollo del asunto". Art. 117 (inciso segundo, en parte): "El abogado que presta servicios profesionales en una empresa de auditoría debe obtener el consentimiento expreso de su cliente para la revelación de la información relativa a sus asuntos con ocasión de cada auditoría que incluya dicha información". 
$\mathrm{El}$ art. 52 regula el consentimiento presunto. La necesidad de su reconocimiento por el CEP-2011 se explica, como se ha dicho, por la amplitud del ámbito de la información protegida por el deber de confidencialidad. Por esta razón, el consentimiento presunto no opera aquí en términos estrictamente subsidiarios respecto del consentimiento expreso. A diferencia de lo que sucede con la ética médica y la causa de justificación en el derecho penal, no es necesario que el cliente se encuentre en una situación tal que no sea posible al abogado obtener su consentimiento expreso para que la regla opere y justifique la revelación de información por parte del abogado. Ciertamente, en esos casos puede operar la institución; ${ }^{18}$ pero no opera sólo en ellos. El objetivo del art. 52 es desinhibir la correcta y eficaz prestación de los servicios profesionales del abogado. Por esa misma razón, en principio el criterio sobre el que se basa la presunción es objetivo: la conveniencia de la revelación para la prestación exitosa de los servicios profesionales consiste en su carácter de medio idóneo y razonablemente (no estrictamente) necesario para el logro del fin. Por cierto, el criterio objetivo se enmarca en un contexto de fines y medios legítimos que es definido autónomamente por el cliente (arts. $3^{\circ}, 28$ y 29). Por tal razón, el consentimiento presunto no opera contra la voluntad expresa del cliente.

La oración final del art. 52 establece que en caso de duda se debe confidencialidad (in dubio, pro fidem). La "duda" debe entenderse en el doble sentido contextual arriba expuesto: en su sentido objetivo enmarcado por una definición autónoma del cliente. O sea, la duda se refiere tanto a la idoneidad y necesidad de la revelación como medio, como también a su correspondencia más verosímil a la voluntad del cliente. Que el abogado deba confidencialidad implica que en caso de duda sólo puede revelar la información contando con el consentimiento expreso del cliente.

El art. 101 admite el consentimiento presunto para justificar la intervención del abogado en los medios de comunicación. El art. 117 inciso segundo lo excluye como justificación de la revelación de información confidencial a la empresa de auditoría para la cual trabaja el abogado.

\section{4}

La revelación no consentida por el cliente

\section{$\int 3$. Revelación no consentida por el cliente}

Artículo 53. Deber de revelar. El abogado debe revelar la información sujeta a confidencialidad para evitar la comisión o consumación de un crimen.

\footnotetext{
18 En casos de ausencia, incapacidad transitoria o permanente del cliente, el consentimiento presunto opera restringido por el art. 2150 del Código Civil.
} 
Bascuñán - Deber de confidencialidad y secreto profesional del abogado

Artículo 54. Facultad de revelar. El abogado puede revelar información sujeta a confidencialidad:

a) para evitar un serio peligro de muerte o de grave daño corporal para una o más personas;

b) para evitar la comisión o consumación de un simple delito que merezca pena aflictiva;

c) para obtener consejo ético profesional, siempre que la revelación se haga a otro abogado bajo confidencialidad;

d) para defenderse de una imputación grave formulada en contra suya o de sus colaboradores en relación con el servicio profesional prestado al cliente; o en relación con hechos en los cuales tuvo parte el cliente;

e) para cobrar los honorarios que le son debidos;

f) para cumplir con un deber legal de informar o declarar, en los términos del párrafo 4 de este título; o

g) en otro caso expresamente autorizado por las reglas de la ética profesional.

Artículo 55. Necesidad. Los artículos precedentes sólo autorizan al abogado a efectuar la revelación que sea necesaria para el logro del fin que la justifica, a condición, además, de que el abogado no disponga de otro medio practicable y menos perjudicial para el cliente. Esta exigencia es particularmente estricta cuando se trata de la revelación que se efectúa para cobrar honorarios.

Artículo 56. Proporcionalidad. Si el hecho que el abogado intenta impedir o la imputación de la que se defiende no son atribuibles al cliente, el abogado sólo se encuentra autorizado a revelar información sujeta a confidencialidad cuando el mal que con ello evita es sustancialmente mayor que el que causa. Esta exigencia es siempre aplicable a la revelación efectuada para cobrar honorarios.

Artículo 57. Consideración debida a la defensa en juicio penal. Si la revelación ordenada o autorizada por los artículos 53 y 54 (a) y (b) puede perjudicar la defensa del cliente en cualquier etapa de un procedimiento penal, el abogado debe adoptar previamente medidas razonables encaminadas a evitar ese perjuicio. El abogado que no dispone de medidas para evitar ese perjuicio no está obligado a hacer revelaciones. Si la defensa penal del cliente está a cargo de otro abogado, la revelación puede ser efectuada a este último.

Artículo 58. Advertencia al cliente. No falta a la ética profesional el abogado que advierte a su cliente que revelará información para lograr mediante esa advertencia alguno de los fines previstos en los artículos 53 y 54, a condición que la advertencia persiga el mismo fin que justificaría la revelación.

Artículo 59. Divulgación en interés general o profesional. No falta a la ética profesional el abogado que expone un caso en que haya intervenido, si con ello favorece el desarrollo de la cultura jurídica o la formación profesional, siempre que adopte las medidas que eviten la identificación del cliente y del caso concreto. 
Los arts. 53 a 59 CEP-2011 corresponden a las reglas 4.1 a 4.6 PD. A estas disposiciones se suma el art. 63 (regla 5.3 PD). La regulación de la revelación de información confidencial aun contra la voluntad del cliente constituye una importante innovación del CEP-2011 en comparación con el CEP-1948. ${ }^{19} \mathrm{El}$ siguiente cuadro comparativo pone de manifiesto:

\begin{tabular}{|c|c|c|c|}
\hline Finalidad justificante de la revelación & CEP-2011 & PD & CEP-1948 \\
\hline Evitación de un crimen & 53 & 4.1 & 12 \\
\hline Evitación de un simple delito & $54(b)$ & 4.2(ii) & 12 \\
\hline $\begin{array}{l}\text { Evitación de peligro de muerte o de grave } \\
\text { daño a la salud }\end{array}$ & $54(\mathrm{a})$ & $4.2(i)$ & 12 \\
\hline Obtención de consejo ético & $54(\mathrm{c})$ & 4.2(iii) & --- \\
\hline $\begin{array}{l}\text { Defensa frente a imputación por hechos } \\
\text { relacionados con el servicio profesional }\end{array}$ & $54(d)$ & 4.2(iv) & 12 \\
\hline $\begin{array}{l}\text { Defensa frente a imputación por hechos del } \\
\text { cliente }\end{array}$ & $54(d)$ & 4.2(iv) & 12 \\
\hline Cobro de honorarios & $54(\mathrm{e})$ & $4.2(\mathrm{v})$ & --- \\
\hline Cumplimiento deber de informar o declarar & $54(f)$ & $4.2(\mathrm{vi})$ & --- \\
\hline Divulgación de interés general & $\begin{array}{c}54(\mathrm{~g}) \\
59\end{array}$ & 4.6 & --- \\
\hline Declaración en caso de abuso del cliente & $\begin{array}{l}54(\mathrm{~g}) \\
63(\mathrm{a})\end{array}$ & $\begin{array}{c}4.2(\text { vii) } \\
5.3(\mathrm{i})\end{array}$ & --- \\
\hline $\begin{array}{l}\text { Declaración en caso de riesgo de condena de } \\
\text { inocente }\end{array}$ & $\begin{array}{l}54-(\mathrm{g}) \\
63-(\mathrm{b})\end{array}$ & $\begin{array}{c}4.2 \text { (vii) } \\
5.3 \text { (ii) }\end{array}$ & --- \\
\hline
\end{tabular}

Tanto el CEP-1948 como el CEP-2011 distinguen entre las causas de revelación imperativa para el abogado y las causas de revelación facultativa. Siguiendo la evolución de la regulación norteamericana, el CEP-2011 aumenta el ámbito de causas de revelación facultativa a expensas de una reducción del ámbito de la revelación imperativa. En general, es constatable una preferencia de la profesión jurídica por reglas que simplemente autoricen la revelación de la información confidencial. Esa autorización - por oposición a la obligación de revelar- deja al profesional un margen de apreciación de las circunstancias que es en general considerado deseable por la profesión. Ello tiene sin embargo un costo. Pues la

\footnotetext{
${ }^{19}$ La disposición pertinente era su Art. 12: "Extinción de la obligación de guardar el secreto profesional. El abogado que es objeto de una acusación de parte de su cliente o de otro abogado, puede revelar el secreto profesional que el acusador o terceros le hubieren confiado, si mira directamente a su defensa. Cuando un cliente comunica a su abogado la intención de cometer un delito, tal confidencia no queda amparada por el secreto profesional. El abogado debe hacer las revelaciones necesarias para prevenir un acto delictuoso o proteger a personas en peligro".
} 
Bascuñán - Deber de confidencialidad y secreto profesional del abogado

apreciación no es discrecional, sino que está sujeta a estándares de razonabilidad (necesidad y proporcionalidad, en la regulación del CEP-2011). Eso implica un margen de riesgo de error en la deliberación del abogado, respecto del cual éste puede ser éticamente responsable.

$\mathrm{El}$ art. 53 establece el único caso de revelación imperativa para el abogado: la que tiene por finalidad evitar la comisión o consumación de un crimen. Esta es una severa restricción del alcance del imperativo de revelación del CEP-1948, que se extendía a la prevención de todo "acto delictuoso". ${ }^{20}$ El concepto de crimen tiene una definición legal en los arts.1 $1^{\circ}, 3^{\circ}$ y 21 del Código Penal. ${ }^{21}$ La distinción entre comisión y consumación tiene por objetivo incluir la evitación de la producción de un resultado que es consecuencia de una acción delictiva cuya ejecución ya se ha terminado (consumación). La evitación de resultados trascendentes a la consumación del delito sólo puede justificarse conforme al art. 54(a).

Es importante observar que a diferencia del CEP-1948 el CEP-2011 no priva del secreto profesional al cliente que comunica a su abogado su intención de cometer un crimen. Desde luego que el abogado no puede hacerse cómplice ni posteriormente encubridor de dicho crimen (arts. $3^{\circ}$ y 25 inciso final). Pero en cuanto excepción al deber de confidencialidad el art. 53 CEP-2011 sólo impone al abogado el deber de revelar la información para evitar ese crimen; no lo autoriza para declarar en contra de su cliente en una investigación o juicio criminal relativos a la tentativa o consumación de dicho crimen. El argumento de que la imposición de una pena al cliente podría impedir la comisión de eventuales crímenes futuros se encuentra fuera de lugar: la finalidad justificante de la revelación es el impedimento de una acción o resultado preciso e inminente; por esa razón el art. 53 utiliza el término "evitar" en vez del término "prevenir", usado por el CEP1948.

El art. 57 prevé una situación en la cual el imperativo del art. 53 deviene en autorización (revelación facultativa): si la revelación puede perjudicar la defensa penal del cliente y el abogado no cuenta con medios que puedan evitar ese

\footnotetext{
${ }^{20}$ La restricción contemplada en la regla 4.1 PD era aún más intensa: sólo se hacía imperativa la revelación para evitar la comisión o consumación de un crimen que atentara contra la vida, la salud, la autonomía sexual o la libertad de las personas. La evitación de los demás crímenes era facultativa conforme a la regla 4.2(ii) PD (infra, nota 16).

${ }^{21}$ Según los cuales un crimen es una acción u omisión voluntaria penada por la ley con cualquiera de las siguientes penas: presidio perpetuo calificado; presidio perpetuo; reclusión perpetua; presidio mayor; reclusión mayor; relegación perpetua; confinamiento mayor; extrañamiento mayor; relegación mayor; inhabilitación absoluta perpetua para cargos y oficios públicos, derechos políticos y profesionales titulares; inhabilitación especial perpetua para algún cargo u oficio público o profesión titular; inhabilitación absoluta temporal para cargos, empleos, oficios o profesiones ejercidos en ámbitos educacionales o que involucren una relación directa y habitual con personas menores de edad; inhabilitación absoluta temporal para cargos y oficios públicos y profesionales titulares; inhabilitación especial temporal para algún cargo u oficio público o profesión titular.
} 
perjuicio, no está obligado a revelar la información confidencial para evitar el crimen. El sentido y alcance de esta regla se explica más adelante.

El art. 54 establece las situaciones en las cuales se faculta al abogado para revelar la información confidencial, sin obligarlo a ello.

(a) La evitación de un serio peligro de muerte o de grave daño corporal para una o más personas. Esta regla convierte en revelación facultativa el imperativo del CEP-1948 de hacer las revelaciones necesarias para "proteger a personas en peligro". Obsérvese que no se requiere que el peligro provenga de una acción u omisión punible o sancionable, ni siquiera ilícita. Es concebible una situación de riesgo en abstracto permitido que sin embargo genere en concreto un peligro cuya evitación justifique éticamente la revelación de la información confidencial. El peligro de suicidio del cliente deber ser analizado por el abogado bajo el principio de respeto a la autonomía del cliente $\left(\right.$ art. $3^{\circ}$ ).

(b) La evitación de la comisión o consumación de un simple delito que merezca pena aflictiva. Esta regla convierte en revelación facultativa el imperativo del CEP-1948 de prevenir un acto delictuoso, restringiendo además la autorización a la evitación de la comisión o consumación de simples delitos sancionados por la ley con pena aflictiva. Conforme al art. 37 del Código Penal, las penas de simples delitos que se reputan aflictivas son las de presidio, reclusión, confinamiento, extrañamiento y relegación menores en sus grados máximos. La evitación de la comisión o consumación de faltas o de simples delitos sancionados por la ley con penas no aflictivas no justifica la revelación de información privilegiada, a menos que sea aplicable al caso el art. 54(a). ${ }^{22}$

(c) La obtención de consejo ético profesional, siempre que la revelación se haga a otro abogado bajo confidencialidad. La consejería ética es una especialidad profesional en los sistemas jurídicos más desarrollados. Entendido el consejo ético profesional como asesoría jurídica en el sentido del art. 15, la segunda parte de la regla es superflua: el abogado que solicita consejo es cliente y el abogado que aconseja debe confidencialidad en los términos de los arts. $7^{\circ}$ y 46 . Además, la consejería ética es objetivamente conveniente para la exitosa prestación del servicio profesional, por lo que en principio se encuentra cubierta por el consentimiento presunto del cliente (art. 52). Eso hace también redundante la primera parte de la regla. Con todo, la regla tiene un campo propio de operatividad allí donde el cliente ha prohibido la revelación de información confidencial en el sentido del art. 52 y no obstante ésta se hace necesaria para la obtención de

\footnotetext{
${ }^{22}$ La regla 4.2(ii) PD era más amplia; además de la evitación de la comisión o consumación de los crímenes no comprendidos en la regla 4.1 (supra, nota 20), autorizaba la revelación de información confidencial para evitar la comisión o consumación de cualquier simple delito que atentara contra la vida, salud, autonomía sexual o libertad de las personas. El Consejo 2009-2011 consideró preferible el uso de criterios formales para definir el ámbito de la revelación imperativa y facultativa (Acta $\mathrm{N}^{\circ}$ 10/2009, de 27 de julio).
} 
Bascuñán - Deber de confidencialidad y secreto profesional del abogado

consejo ético. Esa es la función de su previsión expresa en el CEP-2011: clarificar la legitimidad de la revelación de información confidencial que es necesaria para la obtención del consejo ético, aun contra la voluntad del cliente.

(d) La defensa de una imputación grave formulada en contra suya o de sus colaboradores, ya sea (aa) en relación con el servicio profesional prestado al cliente o (bb) en relación con hechos en los cuales tuvo parte el cliente. La primera hipótesis de la regla permite al abogado la revelación necesaria para defenderse frente a imputaciones graves de infracción de deberes legales o ético-profesionales con ocasión de su servicio profesional. Este es el campo indiscutido de aplicación de la regla del art. 12 CEP-1948. La segunda hipótesis de la regla, junto con la regla del art. 63(a), permite al abogado deslindar el servicio profesional lícitamente prestado al cliente, principalmente de asesoría jurídica, de los hechos ilícitos imputados a su cliente. Para efectos de la aplicación del art. 56 a esta situación, debe tenerse presente que la eventual responsabilidad del cliente por los hechos ilícitos que le son imputados no implica atribuibilidad de la imputación de responsabilidad por esos hechos al abogado. Para que la imputación a éste sea atribuible al cliente, es indispensable que él haya contribuido a su formulación. Esto implica que si el cliente no ha contribuido a la formulación de la imputación contra el abogado éste debe confidencialidad en todo el margen en que el perjuicio que ello le acarree o pueda acarrearle no sea "sustancialmente mayor" que el perjuicio que la revelación acarree al cliente (art. 56).

(e) El cobro de honorarios debidos. La fundamentación de una demanda de cobro de honorarios exige revelar información relativa al cliente, o sea, información confidencial conforme al art. $7^{\circ}$. Por cierto, dentro de esa información puede haber contenidos equivalentes a las "confidencias" del art. 12 CEP-1948, o sea, los "hechos confidenciales" que conforme a la jurisprudencia del Consejo no pueden ser revelados en caso alguno con ocasión del cobro de honorarios. ${ }^{23}$ La manera que tiene el CEP-2011 de mantener ese punto de vista es intensificando expresamente la exigencia de necesidad racional de la revelación para el logro del cobro de honorarios (art. 55 segunda oración) y aplicando al caso la exigencia de preponderancia del mal que se pretende evitar (art. 56 segunda oración), que en este caso es la omisión de pago, aunque dicho mal sea atribuible al cliente. De este modo, el abogado no puede efectuar revelaciones que no sean absolutamente imprescindibles o que irroguen al cliente un perjuicio mayor o igual que el que irrogaría al abogado la falta de pago de los honorarios.

(f) Cumplimiento de un deber legal de informar o declarar, en los términos del párrafo 4 de este título. Esta regla admite que un abogado puede verse judicial o administrativamente compelido a informar o a declarar y que esa revelación jurídicamente compelida puede justificarse éticamente como revelación facultativa, con tal que el abogado cumpla los requisitos especialmente establecidos en el $\ 4$ del título iv. La ética profesional no asume irreflexivamente la legitimidad de los

\footnotetext{
23 Supra, nota 3.
} 
imperativos legales de revelar información del cliente que es confidencial conforme al art. $7^{\circ} \mathrm{CEP}-2011$.

(g) Otro caso expresamente autorizado por las reglas de la ética profesional. Como todas las reglas supletorias de remisión a otras disposiciones legales sobre la materia, el art. 54(g) resulta a primera vista superfluo. No obstante, esta regla cumple la importante función de prevenir al intérprete contra la justificación de la revelación por colisión de deberes o bajo alguna otra estructura de ponderación. Tal como ella lo exige, la justificación de la infracción al deber de confidencialidad requiere autorización expresa por las reglas de la ética profesional. Los dos casos de autorización expresa a revelar información aun contra la voluntad del cliente consagrados por el CEP-2011 fuera del catálogo del art. 54 se encuentran en los art. 59 y 63 .

Los arts. $\mathbf{5 5}$ y $\mathbf{5 6}$ establecen dos requisitos de racionalidad prospectiva que sujetan el cumplimiento del imperativo de revelación del art. 53 y el ejercicio de las autorizaciones de revelación del art. 54 al principio de proporcionalidad. Ambas reglas proceden de las causas de justificación del Código Penal (art. $10 \mathrm{~N}^{\circ} 4$ circunstancia segunda y $\mathrm{N}^{\circ} 7$ ).

El art. 55 establece el requisito de proporcionalidad en sentido amplio (necesidad racional del medio empleado), que naturalmente supone un juicio razonable de idoneidad de la revelación como medio para obtener el fin que la justifica. La regla incluye además una exigencia de subsidiariedad; la medida de la intensidad de esta exigencia debe subordinarse a la medida en que el caso corresponda o no a una situación de legítima defensa: mientras menos corresponda, mayor es su intensidad.

El art. 56 establece el requisito de proporcionalidad en sentido estricto (ponderación), para el caso en que el estado de cosas que se intenta evitar mediante la revelación no sea atribuible al cliente. En tal caso, se está sacrificando su interés en una situación de estado de necesidad agresivo, como la que contempla el art. $10 \mathrm{~N}^{\circ} 7$ del Código Penal para el sacrificio de intereses patrimoniales. De ahí la exigencia de preponderancia del interés que se pretende proteger (mal que se intenta evitar con la revelación) frente al interés del cliente que se sacrifica para su protección (mal que se causa con la revelación). ${ }^{24}$

El art. 57 se pone en el caso de que la revelación imperativa o facultativamente justificada como medio para evitar la comisión o consumación de crímenes o simples delitos legalmente sancionados con pena aflictiva -arts. 53, 54(b) - pueda perjudicar la defensa penal del cliente. El caso más obvio es el de la defensa por la comisión del delito cuya consumación se intenta evitar con la

${ }^{24}$ Obsérvese que la preponderancia requerida por el art. 56 es más intensa que la exigida por la nueva regla del estado de necesidad del art. $10 \mathrm{~N}^{\circ} 11$ circunstancia 3a, introducida por la Ley 20.480 (D.O. 18 de diciembre de 2010). 
Bascuñán - Deber de confidencialidad y secreto profesional del abogado

revelación de la información. Por ejemplo, si la indicación del lugar donde se encuentra instalado el artefacto incendiario da a la policía la oportunidad de hallar prueba incriminatoria de la intervención del cliente en su colocación. Pero más importantes para la práctica son los casos en que la evitación de la comisión o consumación de un delito permite producir prueba acerca de motivos recurrentes o patrones de comportamiento, que corresponden a las circunstancias de los crímenes o delitos cometidos por el cliente en el pasado. En todos estos casos, la revelación de la información privilegiada implica en sus resultados una violación del derecho del imputado o acusado a no autoinculparse. Esta es una razón por la cual se objeta en la regulación ética comparada la existencia de un imperativo ético de revelación para evitar crímenes o delitos. La regla 4.3 PD solucionaba este problema en los siguientes términos estableciendo tres normas: (i) el abogado defensor debe siempre adoptar medidas que impidan el perjuicio para la defensa antes de hacer la revelación; (ii) el abogado que (ya) no es defensor debe transferir el problema al defensor, y, (iii) en caso de no disponerse de medidas que eviten el perjuicio para la defensa ya no se está bajo el imperativo del art. 53: la revelación deviene en facultativa para el abogado. ${ }^{25}$ Esta regla fue objeto de una intensa discusión en el Consejo 2009-2011. ${ }^{26}$ De las tres normas antedichas, el art. 57 sólo conservó intacta la última. La alteración de la primera norma, calificando las medidas razonables de evitación del perjuicio para la defensa como "medidas razonables encaminadas a evitar ese perjuicio" se basa en una analogía con las medidas de mitigación de daños que es improcedente, porque aquí no se trata de medidas fácticamente disponibles. La disponibilidad de estas medidas depende de la regulación penal y procesal penal: si la ley permite al imputado obtener beneficios como contrapartida de la entrega de información y si esos beneficios tienen tanto peso que pueden contrarrestar las consecuencias desfavorables para el cliente de la prueba incriminatoria que produce la revelación de información, entonces el abogado debe adoptarlas antes de hacer la revelación. Esto implica que no se trata de una obligación de medios, como inconsistentemente deja entender la expresión "encaminadas a...", sino de resultados; dado que son medidas que excluyen convencionalmente el perjuicio para la defensa su efecto es binario: si se las adopta válidamente, excluyen el perjuicio; si no, no. Por eso, la consideración de la norma como obligación de medios demuestra un error en la comprensión de la naturaleza de estas medidas. En lo que respecta a la modificación de la segunda norma, haciendo de la transferencia del problema al abogado defensor una cuestión meramente facultativa, ello es una demostración no ya de incomprensión de la norma, sino derechamente de falta de consideración por la defensa penal, por desconfianza en la corrección del abogado defensor. En todo caso, al menos la

\footnotetext{
25 "Consideración debida a la defensa en juicio penal. En los casos en que la revelación mandada o autorizada por las reglas 4.1 [i.e., art. 53], 4.2 (i) y (ii) [i.e., art, 54(a) y (b)] pueda perjudicar la defensa del cliente en un juicio penal, el abogado debe adoptar previamente medidas razonables para evitar ese perjuicio. Si es otro el abogado encargado de la defensa penal del cliente, debe hacer la revelación a éste. El abogado que no dispone de medidas para evitar ese perjuicio no está obligado a hacer revelaciones". (PD-ii-5.3(i)).

${ }^{26}$ Acta $\mathrm{N}^{\circ} 13 / 2009$, sesión de 13 de septiembre.
} 
norma del art. 57 mantiene el efecto liberador de responsabilidad ética de la comunicación que el abogado hace de la situación al defensor penal del cliente.

El art. 58 admite la coacción al cliente bajo amenaza de revelación de su información confidencial como un medio legítimo y menos lesivo para el cliente que la revelación, siempre y cuando la condición impuesta bajo amenaza corresponda al mismo fin que justificaría la revelación. De otro modo, el abogado comete chantaje (amenazas condicionales, según los arts. $296 \mathrm{~N}^{\circ} 1$ o 2, o 297 del Código Penal).

El art. 59 cierra el $\int 3$ del título iv estableciendo una autorización de divulgación de información confidencial en interés colectivo. En este caso, los requisitos de proporcionalidad son sustituidos por un deber de evitar la identificación del cliente y el caso concreto.

El secreto profesional

\section{$\int 4$. Consideración debida al secreto profesional}

Artículo 60. Deber de cautelar el secreto profesional. Si un abogado es requerido por la ley o la autoridad competente para informar o declarar sobre una materia sujeta a confidencialidad, el abogado debe procurar que le sea reconocido el derecho al secreto profesional.

En observancia de este deber, el abogado actuará de conformidad con las siguientes reglas:

a) Interpretación de la ley favorable a la confidencialidad. El abogado debe interpretar las disposiciones constitucionales y legales que lo eximen del deber de informar o declarar del modo que mejor garantice el cumplimiento de su deber de confidencialidad.

b) Prerrogativa de calificación. El abogado debe limitarse a expresar que los hechos están amparados por el secreto profesional y abstenerse de fundamentar esa calificación si esa justificación pudiere comprometer ese secreto.

c) Deber de impugnar. En general, el abogado debe realizar las actuaciones razonables dirigidas a impugnar las decisiones de la autoridad que le ordenan declarar sobre materias que son objeto de secreto profesional.

Artículo 61. Obligación de cerciorarse de la relevación del derecho al secreto profesional. El abogado que ha sido informado por terceros de que ha sido relevado por su cliente del secreto profesional debe comprobarlo personalmente, en observancia del artículo 51. Si fuere necesario, el abogado debe solicitar a la 
Bascuñán - Deber de confidencialidad y secreto profesional del abogado

autoridad que realice las actuaciones que le permitan comunicarse con el cliente. El abogado que no ha podido cerciorarse se encuentra bajo secreto profesional.

Artículo 62. Licitud ética de la negativa a declarar. No falta a la ética profesional el abogado que se niega a declarar o a informar sobre materias sujetas a confidencialidad con fundamento en su derecho al secreto profesional.

Artículo 63. Autorización ética para declarar. Citado a declarar como testigo, el abogado está facultado para revelar información sujeta a confidencialidad, sin cumplir con los resguardos referidos en el artículo 60, en los siguientes casos:

a) si tiene razones fundadas para considerar que el servicio profesional por él prestado fue utilizado por el cliente para realizar un hecho que se le imputa a ese cliente como crimen o simple delito; o como otro hecho grave que la ley sanciona y ordena investigar; o

b) si la información se refiere a un cliente fallecido y su revelación puede evitar que un imputado que haya sido formalizado sea erróneamente condenado por crimen o simple delito.

Artículo 64. Extensión del derecho al secreto profesional a los documentos y demás soportes que contengan información confidencial. Las reglas de este párrafo se extienden en iguales términos a la orden o requerimiento por la ley o la autoridad competente de incautar, registrar, entregar o exhibir documentos u otros soportes físicos, electrónicos o de cualquiera naturaleza que contengan información sujeta a confidencialidad. La regla se extiende a la información producida por el abogado con carácter confidencial, sea que se encuentre en su poder o en el de su cliente.

Los arts. 60, 61, 63 y 64 corresponden a las reglas 5.1 a 5.4 PD. El art. 62 corresponde a una idea regulativa descartada por la PD. ${ }^{27}$

El tratamiento que el CEP-2011 hace del secreto profesional constituye su mayor innovación conceptual y sistemática. El art. 10 CEP-1948 no distinguía entre el deber prima facie de guardar reserva y el deber definitivo de guardar reserva, a pesar de encontrarse en conflicto con un deber legal de informar o declarar. Esta falta de diferenciación se expresaba en el uso de un solo término - "secreto profesional"- y su consideración como "derecho-deber". La regulación anglonorteamericana expresa esa distinción diferenciando entre el deber éticoprofesional de confidencialidad y el privilegio legal de la relación abogado-cliente. Esa diferenciación es recogida ahora por el CEP-2011 en tres lugares precisos:

(i) el art. $7^{\circ}$ distingue entre el deber ético de confidencialidad y el derecho legal al secreto profesional;

27 PD-iii, regla 5.2. 
(ii) el art. 54(f) justifica éticamente como revelación facultativa del abogado la que se hace para cumplir con un deber legal de informar o declarar;

(iii) el $\mathbb{\int} 4$ del título iv considera al secreto profesional como un derecho (en rigor, una exención) reconocido por normas constitucionales y legales, que el abogado tiene el deber ético de invocar para cumplir su deber ético de confidencialidad.

La diferenciación entre ambas instituciones se basa en tres órdenes de consideraciones: una analítica, una sistemática y una valorativa.

Analíticamente, la diferencia entre el deber de confidencialidad y el secreto profesional corresponde a la diferencia que existe entre una norma de comportamiento (prohibición/imperativo) aplicable prima facie a un caso y la solución de una antinomia afirmando la preponderancia de esa norma. El secreto profesional es la exención al deber de declarar o informar en colisión con el deber de confidencialidad que afirma la preponderancia de éste respecto de aquél.

Sistemáticamente, la diferencia entre el deber de confidencialidad y el secreto profesional corresponde a la diferencia que existe entre una norma de comportamiento estatutaria (corporativa) y una exención jurídica que hace posible el cumplimiento de la norma de comportamiento estatutaria. ${ }^{28}$ Esta diferencia es contingente: si la ética profesional del abogado estuviera regulada por ley, ella desaparecería. En las actuales condiciones institucionales de aprobación del CEP2011, la diferencia es no obstante crucial.

Valorativamente, la diferencia entre el deber de confidencialidad y el secreto profesional corresponde a la diferencia que debe existir entre los fundamentos del primero y los fundamentos de su consideración como deber preponderante en caso de colisión con un deber legal de informar o declarar.

La PD asumió las tres consideraciones y desarrolló una teoría de la preponderancia del deber de confidencialidad que implicaba una restricción de su ámbito en tanto deber preponderante. Conforme a esta teoría, dominante en el derecho anglonorteamericano, la preponderancia del deber de confidencialidad exige dotarlo de un peso específico mayor que el interés público en la obtención de información verosímil. Ese peso se encuentra indiscutiblemente en el ejercicio de una función de defensa por el abogado, en especial la defensa penal, pero comprensiva de toda representación de intereses del cliente en procedimientos que adjudican derechos o atribuyen responsabilidades. Toda información relativa a

\footnotetext{
${ }^{28}$ No se debe perder de vista que el deber de confidencialidad en tanto norma de comportamiento prima facie aplicable al caso también tiene rango jurídico-penal (arts. 231, 247 inciso segundo del Código Penal). El ámbito de información cubierta por una y otra prohibición es incierto; en todo caso, no es mayor que el ámbito cubierto por el deber de confidencialidad establecido por el CEP2011.
} 
Bascuñán - Deber de confidencialidad y secreto profesional del abogado

asuntos del cliente, recibida o producida por el abogado con ocasión de una defensa está protegida por el secreto profesional. Aunque el caso de la asesoría jurídica es discutido en el derecho comparado, la PD se inclinó por considerarlo también como una situación que otorga a la información recibida o producida por el abogado un peso específico preponderante. En cambio, el mero desempeño del abogado como mandatario en una gestión civil o comercial del cliente no puede tener ese peso específico. No obstante, dicho desempeño se encuentra tan cubierto por el deber ético de confidencialidad como la defensa y la asesoría. Por esta razón, el ámbito protegido por el secreto profesional (exención jurídica) es más restringido que el ámbito cubierto por el deber (ético) de confidencialidad. ${ }^{29}$ En mi opinión, esta teoría es enteramente correcta.

El Consejo 2009-2011 asumió la consideración analítica (que es lógicamente necesaria) y la consideración sistemática (que es fácticamente indesmentible), pero no asumió la consideración valorativa. La razón de ello se encuentra en que la cultura jurídica chilena ha procedido durante el siglo XX en sentido inverso al de la cultura jurídica anglonorteamericana. En el CEP-1948 adoptó la terminología de la exención establecida por el Código de Procedimiento Civil, que en su sentido natural y obvio es sumamente restrictiva, pero que se la ha interpretado amplísimamente. Es decir, se ha basado una concepción amplia del ámbito del deber ético de confidencialidad en una interpretación amplia de las normas legales sobre secreto profesional. ${ }^{30}$ Por tal razón, la idea de que una y otra institución pueden tener ámbitos de protección distintos es intuitivamente rechazada.

\footnotetext{
${ }^{29} \mathrm{DP}-\mathrm{i}-2$.

${ }^{30}$ La interpretación amplia del concepto "confidencia" encuentra su principal apoyo en la sentencia de la Corte Suprema de 13 de mayo de 1954, recaída sobre recurso de queja interpuesto en contra de la sentencia de la Corte de Apelaciones de Santiago de 18 se septiembre de 1853, que revocó la resolución del tribunal de primera instancia que había acogido la oposición del abogado citado a declarar en juicio de alimentos seguido por la hija de su cliente en contra su cliente (Guttman vs. Guttmann, 53 Revista de Derecho y Jurisprudencia, 1954, $2^{\text {a }}$ Parte, Sección 1a , pp. 128-132). La demandante, que había recibido el pago de alimentos por intermedio del abogado de su padre, citó al abogado a declarar acerca de esos pagos. La Corte de Apelaciones sostuvo que los hechos personales de un abogado no pueden considerarse comunicaciones confidenciales en el sentido del art. $360 \mathrm{~N}^{\circ} 1 \mathrm{CPC}$ y por lo tanto no están cubiertos por el secreto profesional. La Corte Suprema, en cambio, sostuvo que "un acto confidencial" realizado por el abogado por instrucciones de su cliente constituye uno de esos "hechos que se le [ha] comunicado confidencialmente" en el sentido del art. $360 \mathrm{~N}^{\circ} 1$ CPC. No puede excluirse que una consideración atenta del caso, que vincule el desempeño del mandato civil de pago de alimentos a una eventual defensa judicial y respete la prerrogativa de calificación del abogado, llegue a un resultado similar al de la Corte Suprema. En sus propios términos, sin embargo, la decisión de la Corte Suprema carece por completo de fundamento.
} 
En razón de la disparidad de apreciaciones acerca de la consideración valorativa, ${ }^{31}$ el Consejo 2009-2011 decidió aprobar una regulación que se mantiene neutral sobre el punto. Los arts. 60 a 64 adoptan como premisa que la ética profesional tiene rango estatutario, por lo que no puede definir el sentido y alcance de las disposiciones legales que definen el secreto profesional. Pero no adopta una posición respecto de las condiciones bajo las cuales el deber de confidencialidad debería ser considerado por el abogado como preponderante frente a deberes legales de informar o declarar.

En general, la cuestión de cuál sea el fundamento del secreto profesional en tanto exención jurídica y cuáles sean las consecuencias de ello para la determinación del ámbito de la información cubierta por el secreto profesional no es directamente pertinente para la adjudicación de responsabilidad disciplinaria. Los arts. 60(b), 60(c) y 61 son aplicables cualquiera sea la respuesta que se dé a esas cuestiones. La aplicación del art. 60(a) puede verse afectada por la teoría que se tenga respecto de la institución del secreto profesional, lo mismo que la aplicación del art. 62. Pero es claro que la cuestión resulta directamente pertinente más bien para la función de amparo profesional del Colegio que para su ejercicio de jurisdicción disciplinaria.

$\mathrm{El}$ art. 60 establece en su primer inciso el deber ético de invocar el secreto profesional cuando se es compelido a informar o declarar, a fin de preservar la confidencialidad éticamente debida al cliente.

El inciso segundo establece tres deberes que se entienden como consecuencia del deber anterior:

(i) El deber interpretar el derecho vigente de modo favorable a la confidencialidad debida. Siendo el secreto profesional una exención reconocida por el derecho vigente, el cumplimiento del deber de invocarlo exige del abogado un desempeño argumentativo vinculado a su interpretación.

(ii) El deber de ejercer una prerrogativa de calificación. Esta regla mantiene lo dispuesto por el art. 10 CEP-1948: "debe el letrado (...) con toda independencia de criterio, negarse a contestar las preguntas que (...) lo expongan a ello" [i.e., violar el secreto profesional]. La regla se pone en el caso de que la justificación ante el tribunal de encontrarse la información cubierta por el secreto profesional exija al abogado revelar parte de esa información. En los sistemas de juicio por jurado, la cuestión se resuelve in camera, es decir, en audiencia privada ante el juez, quien a la luz de todos los hechos informados por el abogado citado a declarar como testigo decide si se encuentra o no amparado por el privilegio de la relacióncliente; si el juez decide a favor del abogado, la información permanece

\footnotetext{
${ }^{31}$ La controversia sobre este punto atraviesa toda la discusión del $\int 5$ PD por el Consejo 20092011: Acta $N^{\circ} 13 / 2009$, sesión de 14 de septiembre; Acta $N^{\circ}$ 14/2009, sesión de 28 de septiembre; Acta $\mathrm{N}^{\circ} 15 / 2009$, sesión de 19 de octubre.
} 
Bascuñán - Deber de confidencialidad y secreto profesional del abogado

confidencial. En ausencia de un procedimiento de esa naturaleza en el derecho chileno, lo razonable es que el tribunal que adjudicará la cuestión reconozca al abogado una prerrogativa de calificación. Esta tesis fue sostenida por el Colegio de Abogados en un acuerdo de 27 de mayo de 1952, como premisa para concluir que un juez del crimen no puede allanar el despacho de un abogado para incautar documentos y luego, a la vista de todos ellos, discernir cuáles están cubiertos por el secreto profesional y cuáles no lo están. ${ }^{32} \mathrm{El}$ párrafo preciso de este acuerdo sobre el punto merece ser reproducido:

Puesto que los textos de los Códigos de Procedimiento Penal y Civil amparan el deber moral y jurídico en que los abogados se encuentran de guardar el sigilo de las confidencias recibidas en razón de su oficio, permitiéndoles negarse a declarar en juicio, civil o penal, sobre las materias que las comprendan o comprometan, obvio es que está entregado a la probidad y conciencia de esos profesionales el correcto ejercicio de ese derecho, porque no sería posible, sin violar el secreto mismo, que el juez estuviera facultado para conseguir la declaración del depositario del secreto, y discriminar en seguida qué partes de esa declaración se llevarán al proceso, dejándose en los autos constancia de ellas, y cuáles continuarán confidenciales, porque desde el momento mismo en que el abogado hiciera al juez partícipe de su confidencia ya el secreto estaría violado y desconocida la norma ética que impone el deber de guardar en reserva cuanto se le confíe en el ejercicio de su profesión. ${ }^{33}$

El nuevo Código Procesal Penal establece un procedimiento de filtro previo por el juez de garantía, para impedir que el Ministerio Público acceda a la información cubierta por el secreto profesional contenida en los documentos incautados (art. 220 inciso cuarto), pero carece de un procedimiento in camera para resolver acerca del secreto profesional invocado por el abogado citado a declarar como testigo. En tales condiciones, el abogado debe exigir le sea reconocida una prerrogativa de calificación de la información poseída como información protegida bajo el secreto profesional.

(iii) El deber de impugnar los actos administrativos o jurisdiccionales que lo compelan a informar o declarar. Esta norma exige al abogado realizar actos

3253 Revista de Derecho y Jurisprudencia (1954), Primera Parte, pp. 38-44.

33 Op. cit., p. 40. El "correcto ejercicio del derecho al secreto profesional" que cabe dejar "a la probidad y conciencia de los abogados" es su prerrogativa de calificación de la información poseída como información que corresponde a aquella que la ley protege con la institución del secreto profesional. En ningún caso significa hacer del juicio discrecional del abogado la medida de la interpretación de las disposiciones legales que reconocen el secreto profesional. En cuanto a la determinación del sentido y alcance de las disposiciones legales relativas al secreto profesional el abogado está sometido a un deber ético de interpretación extensiva conforme al art. 60(a), pero quien tiene la última palabra es obviamente el tribunal con competencia de decisión final. 
procesales; la medida de esa exigencia se encuentra en el carácter "razonable" de la actuación; eso implica ponderar la efectividad de la medida con el esfuerzo extraordinario que ella implica para el abogado.

$\mathrm{El}$ art. 61 reproduce para este contexto la norma establecida por el art. 51 oración tercera.

El art. 62 consagra una regla de desobediencia ética al deber de informar o declarar. La regla fue discutida y en definitiva descartada por la PD, en atención a la aspiración de que las reglas del nuevo CEP fueran reconocidas en un futuro cercano por la legislación o la regulación reglamentaria sobre la ética profesional del abogado. El Consejo 2009-2011 prefirió establecerla, como una forma de declarar la autonomía de la ética profesional respecto del derecho estatal. Naturalmente, la regla sólo exime de responsabilidad disciplinaria al abogado bajo el régimen jurisdiccional del Colegio de Abogados, por ejemplo, frente a una acusación de infracción de los arts. $2^{\circ}, 93$ y 96 CEP-2011. Por sí misma, no puede justificar jurídicamente el desacato al tribunal, ni siquiera en virtud del art. $10 \mathrm{~N}^{\circ}$ 10 del Código Penal. ${ }^{34}$ Además, no cualquier desacato bajo pretexto del secreto profesional queda exento de responsabilidad ética, sino sólo aquel en el que se incurra "con fundamento" en el secreto profesional. Que cuente como fundamento dependerá de la teoría que se tenga sobre el secreto profesional.

El art. 63 es una disposición peculiar. En la medida en que establece dos autorizaciones para declarar en juicio, adopta una decisión acerca del alcance de la institución del secreto profesional. Ciertamente, sus efectos se limitan en principio a la exoneración de responsabilidad disciplinaria por la revelación de información confidencial del cliente bajo el régimen jurisdiccional del Colegio. La operatividad de la regla para efectos de la justificación jurídico-penal, de cara a los arts. 231 o 247 inciso segundo del Código Penal, y/o la consecuente responsabilidad civil por indemnización de perjuicios no puede excluirse pero tampoco afirmarse por el CEP-2011. Por esta razón, dado su carácter facultativo conforme al art. 63, no parece probable que en un futuro cercano los abogados ejerzan la facultad ética que ella les otorga.

La autorización ética al abogado para declarar como testigo y revelar información confidencial de su cliente, sin subordinarse a los deberes del art. 60, procede en dos situaciones:

(a) Cuando el abogado tiene razones fundadas para considerar que el cliente dio un uso ilícito a la asesoría que le prestó, consistente en cometer un crimen, simple delito o infracción cuya gravedad queda demostrada por la existencia de procedimientos investigativos a cargo de funcionarios públicos. La regla incorpora en la ética profesional chilena parte de la institución del "fraude del cliente", propia

\footnotetext{
34 Sí puede servir de apoyo institucional para un argumento de principios o de ponderación de intereses que pretenda justificar el desacato por la vía del art. $10 \mathrm{~N}^{\circ} 10$ del Código Penal.
} 
Bascuñán - Deber de confidencialidad y secreto profesional del abogado

del derecho procesal anglonorteamericano. El sentido y alcance de esta innovación fueron largamente explicados por la PD, en términos que merecen ser transcritos:

El art. 12 CEP declara que "cuando un cliente comunica a su abogado la intención de cometer un delito, tal confidencia no queda amparada por el secreto profesional". De este principio, el mismo artículo deduce luego un deber para el abogado de hacer las revelaciones necesarias para evitar ese delito. Pero el principio produce su efecto institucional directo autorizando al abogado para revelar esa información como testigo en juicio: "tal confidencia no queda amparada por el secreto profesional". Esta regla proviene del canon 37 de la ABA de 1928, que en esta parte es tributario de la excepción del crimen o fraude del cliente, largamente reconocida y desarrollada por el derecho angloamericano [Edna Selan Epstein, The Attorney-Client Privilege and the Work-Product Doctrine, U.S.A, ABA, 2007, Volume I, p. 670 s.]. Tal como se la encuentra actualmente formulada en el Restament of the Law Governing Lanyers del American Law Institute (RLGL-ALI), la excepción comprende dos casos: (i) el caso en que la comunicación del cliente tiene lugar con ocasión de una consulta del cliente efectuada con el propósito, posteriormente realizado, de obtener asistencia para cometer un crimen o fraude o auxiliar a un tercero en su comisión, (ii) el caso en que la comunicación tiene lugar con ocasión del uso por parte del cliente del consejo o de otros servicios del abogado para la comisión o auxilio de un crimen o fraude, independientemente del propósito del cliente al momento de la consulta [ 82 (a) RLGL-AL].

La regla 5.3 (i) [i.e., art. 63(a) CPE-2011] se refiere al segundo caso recién mencionado. Dado que el segundo caso comprende al primero, y que la razón de la excepción se encuentra en que el privilegio del abogado sólo protege el uso conforme a derecho de la información que el abogado provee al cliente, la regulación del primer caso resulta redundante y eventualmente injustificada. El cliente que sin conocer el derecho revela de buena fe una intención que desde el punto de vista del derecho ha de calificarse como delictiva y advertido de ello por el abogado desiste de usar sus servicios no se encuentra respecto de ese abogado en la misma situación del cliente que utiliza de mala fe la información brindada por el abogado para planificar la comisión del acto ilícito. Exponer al primer cliente a una excepción al deber de guardar el secreto afectaría la desinhibición de la relación abogado-cliente que la institución del secreto profesional pretende asegurar. Otorgar al segundo cliente la misma protección afectaría la legitimidad de la institución del secreto profesional. Por otra parte, las excepciones al deber de confidencialidad consagradas en casos semejantes por las reglas 4.1 y 4.2 (ii) [i.e., arts. 53, 54(b) CPE-2011] se explican 
por razones preventivas, que no son extensibles a consideraciones punitivas.

La expresión "crimen o fraude" es traducción literal de la fórmula inglesa respectiva ("crime or fraud") pero entre nosotros no tiene el mismo significado en lo que respecta al primer término y carece de sentido jurídico preciso en lo que respecta al segundo término. Por tal razón, asumiendo que los actos fraudulentos más graves son punibles, la regla 5.3 (i) usa las expresiones "comisión de un crimen o simple delito". Con ello precisa además el ámbito objetivo actualmente cubierto por la regla del Art. 12 CEP, en el sentido de excluir las faltas.

La regla 5.3 (i) extiende esta autorización ética más allá del ámbito de los hechos punibles, incluyendo el caso del cliente que haya usado los servicios profesionales del abogado para la realización de otros hechos ilícitos de gravedad comparable. Esta es otra decisión extremadamente controvertida (..). En principio, es indesmentible que cuando se rebasa el umbral de la punibilidad se priva de relevancia la decisión del legislador para la calificación de la gravedad de la ilicitud y se pierde un criterio de delimitación fácilmente aplicable sin que exista otro igualmente operativo que pueda sustituirlo. Además, una consideración de prudencia aconseja mantener un margen de coincidencia con la actual regulación ética, que sólo se refiere a comportamientos delictivos (Art. 12 CEP). Todas estas son razones de peso para excluir esta ampliación. No obstante, en su favor cabe señalar, en primer lugar, que dada la tendencia del legislador chileno a prescindir de la pena en la regulación de importantes ámbitos de la actividad económica (el derecho de la competencia y el derecho del medio ambiente son casos paradigmáticos), es cuestionable que la punibilidad represente hoy en día el mejor criterio de valoración de la gravedad del ilícito desde el punto de la decisión legislativa. Las razones que toma en consideración el legislador para declarar punible o administrativamente sancionable un comportamiento no se reducen a la valoración del mismo como más o menos grave. Existe, sin duda, una diferencia central asociada a la distinción entre la pena y las demás sanciones y que es de la mayor importancia para la regla 5.3 (i): sólo respecto de la primera existe un interés público de esclarecimiento expresado en el procedimiento de investigación que es propio del proceso penal. Ese es el interés que, unido al interés del abogado a evitar verse asociado a un crimen o simple delito, justifica la exención de responsabilidad ética para el abogado que contribuye al esclarecimiento de los hechos. De aquí que la propuesta incluya como criterio delimitador del ámbito del derecho administrativo sancionador al que se extiende esta exención el que la ley no sólo sancione el comportamiento sino que lo "ordene investigar". Esta 
Bascuñán - Deber de confidencialidad y secreto profesional del abogado

expresión debe entenderse en el sentido de que la legislación haya configurado un procedimiento para el esclarecimiento del hecho tal que exista un órgano público que tenga el deber de investigarlo, ya sea para sancionarlo o formular cargos.

En contra de la regla 5.3 (i), incluso en su formulación restringida a la revelación de antecedentes relacionados con la comisión de crímenes o simples delito, cabe formular razones de peso. La objeción más grave, sin duda, se encuentra en que el testimonio del abogado es requerido en juicio precisamente para probar el hecho cuyo acaecimiento justifica la autorización ética para prestar dicho testimonio. Tratándose de hechos constitutivos de delito, lo anterior significa que el testimonio del abogado es requerido cuando el cliente todavía se encuentra beneficiado con la presunción de inocencia, pero el abogado se entiende autorizado precisamente si asume que el cliente ha cometido el hecho que se le imputa. No obstante, la dificultad se resuelve si se distingue el estándar de evidencia requerido por la regla ética para eximir de deber de confidencialidad al abogado del estándar de evidencia requerido por la ley para justificar la condena, siendo obviamente menor el primero que el segundo. De aquí que la declaración del abogado no pueda contar como prueba indirecta de que el cliente ha cometido el hecho sobre el cual recae la declaración. En todo caso, vale la pena reiterar que el estándar de evidencia de la regla ética exige razonabilidad, excluyéndose con eso conjeturas infundadas.

Aun salvándose la objeción anterior, cabe observar también en contra de la regla 5.3 (i) que su inclusión crea un riesgo de abuso por parte de los órganos investigadores y de descrédito de la profesión de abogado por la delación de los clientes. Sostienen los miembros del Grupo que rechazan incluir esta regla que, en el supuesto de hecho de la misma, el abogado se encuentra amparado por dos instituciones que lo eximen de declarar, pues, si es considerado como tercero ajeno al hecho investigado está cubierto por el secreto profesional y si es considerado como partícipe dispone del derecho a no autoinculparse. La inclusión de la regla sugeriría el reconocimiento de una situación en que no hay deber de guardar el secreto profesional ni derecho a no declarar en perjuicio propio, sino deber de declarar como testigo, dejando en consecuencia al abogado en posición de delator forzoso de su cliente. A favor de la regla, no obstante, cabe señalar que desde el punto de vista de las reglas de la ética profesional el riesgo de abuso queda suficientemente neutralizado por la prerrogativa de calificación reconocida por la regla 5.2-(ii) [art. 60(b) CEP-2011]: el abogado no tiene por qué dar razones acerca de la consideración de su situación como no comprendida, en lo que interesa aquí, por la regla 5.3 (i) si con ello revelaría el secreto que debe guardar. 
Por otra parte, la regla no convierte al abogado en delator de sus clientes sino frente a requerimiento judicial y en casos justificados. En efecto, la exoneración de responsabilidad ética por cumplir un deber legal de declarar como testigo sin ampararse en el secreto profesional procede sólo respecto de clientes que han abusado de sus servicios, usándolos para infringir las normas de comportamiento más importantes de la comunidad, esto es, de clientes cuyo interés no es merecedor del privilegio del secreto profesional, atendidos los fundamentos de la propia institución legal. Finalmente, la ausencia de esta regla, lejos de beneficiar la posición del abogado, aumenta el dilema al que se enfrenta cuando se da el supuesto de la misma: o incrementa el riesgo de ser imputado por coautoría o complicidad con su cliente y de asociar su nombre a una situación infraccional grave, si calla, o corre el riesgo de ser acusado por violación de secreto profesional, si revela. La regla ofrece al abogado una salida a ese dilema en el nivel de la ética profesional, quedando a su cargo el reconocimiento de esta alternativa ética en el nivel de la legislación. ${ }^{35}$

(b) Cuando la información corresponde a un cliente fallecido, y su revelación puede evitar la condena de un inocente; la regla incorpora en la ética profesional un punto de vista defendido por un sector de la doctrina y jurisprudencia norteamericanas, representado por la opinión disidente de la jueza asociada Sandra Day O'Connor en el caso Swidler \& Berlin v. United States 524 U.S. 399, 411-416 (1998). ${ }^{36}$

El art. 64 consagra dos normas. En su primera oración, la disposición recoge la doctrina del producto del trabajo del abogado como información cubierta por la confidencialidad, respecto de la cual se tiene el deber ético de invocar el secreto profesional. La regla generaliza como principio ético el contenido del art. 220 del Código Procesal Penal. En su segunda oración, la disposición extiende la consideración anterior al producto del trabajo del abogado que se encuentra en poder del cliente. La regla generaliza una interpretación del art. 220 inciso tercero CPP, conforme a la cual el imputado (i.e., el cliente) se encuentra comprendido por la expresión "personas a quienes la ley reconoce la facultad de no prestar declaración" en virtud de lo dispuesto por el art. 93-g CPP.

La clarificación del estatus de las conversaciones del cliente con el abogado, cuando es el cliente y no el abogado la persona citada a declarar en un juicio no penal, se encuentra pendiente.

\footnotetext{
35 PD-iii-5.3-a

36 PD-iii-5.3-b.
} 
Bascuñán - Deber de confidencialidad y secreto profesional del abogado

6

La confidencialidad entre abogados de contrapartes

Artículo 110. Consentimiento en mantener una información como confidencial. El abogado debe confidencialidad al abogado de la otra parte si se ha obligado expresamente a respetarla. Con todo, no podrán hacerse valer en juicio, aun a falta de pacto expreso, los documentos y demás antecedentes que se hayan obtenido del abogado de la contraparte en el curso de la negociación de avenimientos, conciliaciones y transacciones frustradas, a menos que la conducta procesal de la otra parte justifique inobservar ese deber recíproco.

Artículo 111. Facultad para compartir la información con el cliente. El abogado que recibe información bajo confidencialidad del abogado de otra parte está autorizado para compartir esa información sólo con el cliente en cuya consideración esa información le fue revelada.

Los arts. 110 y 111 tienen su origen en las reglas 6.1 y 6.2 PD. A diferencia de la PD, en el CEP-2011 estas disposiciones no se encuentran ubicadas en el mismo apartado sistemático que las reglas sobre el deber de confidencialidad para con el cliente (título iv de la sección segunda), sino en su sección cuarta ("deberes en la relación profesional entre abogados y terceros"), título i ("relación entre abogados cuyos deberes fiduciarios se vinculan con clientes distintos").

La PP no contemplaba reglas sobre la materia, en el entendido que su regulación respondía mejor a la consideración de las relaciones entre abogados que al deber de confidencialidad, definido sobre la base de la relación abogado-cliente. Sin embargo, ya en esa oportunidad se manifestó en el Consejo 2007-2009 una postura favorable a mantener la regla del art. 11 CEP-1948, conforme a la cual "la obligación de guardar el secreto profesional abarca las confidencias (...) que sean consecuencia de pláticas para realizar una transacción que fracasó". ${ }^{37}$

La PD propuso al Consejo 2009-2011 tres reglas -6.1, 6.2, 6.3-, que partían de la base que el deber de confidencialidad que pudiera existir entre abogados de contrapartes tenía "una intensidad atenuada en comparación con el deber de confidencialidad del abogado para con su cliente y subordinada a este último deber". ${ }^{38}$ Las reglas establecían, en lo esencial, que la confidencialidad debía

\footnotetext{
37 Acta $\mathrm{N}^{\circ} 15 / 2008$, sesión de 8 de septiembre. Como antes se hizo ver (supra, nota 6), la PP contemplaba una regla sobre confidencialidad entre abogados (regla 1.2), pero que sólo se refería a casos en que los abogados respondían fiduciariamente a un mismo cliente.

38 PP-iii-6. "\$ 6. Deber de confidencialidad para con el abogado de otra parte. / $6.1 \mathrm{El}$ abogado debe confidencialidad al abogado de otra parte cuando consiente expresamente en ello. / 6.2 El abogado que recibe información bajo confidencialidad del abogado de otra parte está
} 
REJ - Revista de Estudios de la Justicia - No 15 - Año 2011

ser aceptada expresamente por el abogado que recibe la información, el cual no obstante se encontraba autorizado para compartir con su respectivo cliente (o con todos sus clientes, en la alternativa más radical) la información recibida y usarla en la prestación de sus servicios profesionales.

El Consejo 2009-2011 discutió las reglas en sus sesiones de 30 de noviembre y de 14 de diciembre de $2009 .{ }^{39}$ El principal objeto de debate consistió en la cuestión de si la confidencialidad de la información compartida en negociaciones fallidas debía quedar sujeta a la aceptación expresa de los abogados involucrados, como lo proponía la regla $6.1 \mathrm{PD}$, o si debía ser establecida derechamente por la regla de la ética profesional, como lo hacía el art. 11 CEP1948. En el contexto de esa discusión, el Presidente del Colegio propuso las siguientes reglas:

Artículo 6.1.

Alternativa 1: Consentimiento en mantener una información como confidencial. El abogado debe confidencialidad al abogado de la otra parte si se ha obligado expresamente a respetarla. Con todo, no podrán hacerse valer en juicio, aun a falta de pacto expreso, los documentos y demás antecedentes que se hayan obtenido del abogado de la contraparte en el curso de una negociación frustrada, a menos que la conducta procesal de la otra parte justifique hacer cesar ese deber de lealtad recíproco.

Alternativa 2: Consentimiento en mantener una información como confidencial. El abogado debe confidencialidad al abogado de la otra parte si se ha obligado expresamente a respetarla.

Artículo 6.2. Facultad para compartir la información con el cliente. El abogado que recibe información bajo confidencialidad del abogado de otra parte está autorizado para compartir esa información con el cliente en cuya consideración esa información le fue revelada. Queda excluida la facultad de revelar la información al cliente si se ha convenido expresamente entre los abogados que no le será comunicada. En cualquier caso, el abogado que haya recibido la información estará autorizado para usarla en el ámbito de su relación fiduciaria con su cliente, en cuanto ese uso sea

\footnotetext{
autorizado para compartir esa información con [el cliente en cuya razón la información le fue revelada] [sus clientes] y para usarla en cumplimiento de sus deberes fiduciarios para con [éste] [éstos]. / 6.3. Salvo por lo dispuesto en contrario en las reglas 6.1. y 6.2. precedentes, son aplicables al deber de confidencialidad que un abogado tiene para con el abogado de otra parte, lo dispuesto en los parágrafos 1 a 5 precedentes". (PD-ii-6). Las expresiones entre paréntesis en la regla 6.2 explicitan el desacuerdo al interior del grupo de trabajo, que se tradujo en la proposición de alternativas de regulación al Consejo.

39 Actas N ${ }^{\circ} 17 / 2009$ y 18/2009.
} 
Bascuñán - Deber de confidencialidad y secreto profesional del abogado

proporcionado y concordante con los fines para los cuales fue revelada, y no comprometa la confidencialidad prometida.

La discusión del Consejo se concentró exclusivamente en la opción por una de las alternativas propuestas para la regla 6.1, aprobándose la primera alternativa. Resuelta esa cuestión, se decidió entregar la responsabilidad por la redacción definitiva de las reglas a otro grupo de trabajo -conducta procesal, relación entre abogados-, atendido su diferente fundamento.

Este cometido fue abordado por el grupo de trabajo sobre integridad en el trato entre abogados, constituido por el Consejo 2009-2011. Su propuesta -PITAfue discutida por la Comisión de Ética un año después, en sesión ordinaria de 15 de diciembre de 2010, en los siguientes términos:

Concluyendo el primer capítulo, en lo que se refiere a la confidencialidad entre abogados, que era el tema que este grupo tenía que zanjar de acuerdo a lo que el Consejo le había solicitado, se acordó mantener la regla mayoritaria que, por una parte, establece que la confidencialidad entre colegas debe ser consentida, no se presume per se, salvo en ciertas condiciones objetivas que la jurisprudencia del Colegio había calificado y que dicen relación con equivalentes jurisdiccionales. Es decir, una vez que fracasa un avenimiento, conciliación o transacción, cuyo objeto era precaver o terminar un conflicto y donde generalmente se van a presentar ofertas superiores a las que se enfrentarían en un juicio, esos antecedentes no puedan presentarse en juicio.

Artículo 5. Consentimiento en mantener una información como confidencial. El abogado debe confidencialidad al abogado de la otra parte si se ha obligado expresamente a respetarla. Con todo, no podrán hacerse valer en juicio, aun a falta de pacto expreso, los documentos y demás antecedentes que se hayan obtenido del abogado de la contraparte en el curso de la negociación de avenimientos, conciliaciones $y$ transacciones frustradas, a menos que la conducta procesal de la otra parte justifique hacer cesar ese deber de lealtad recíproco.

Artículo 6. Facultad para compartir la información con el cliente. El abogado que recibe información bajo confidencialidad del abogado de otra parte está autorizado para compartir esa información sólo con el cliente en cuya consideración esa información le fue revelada. 
El propósito es analíticamente separar entre lo que es el deber de confidencialidad y el secreto profesional hacia los clientes, de una suerte de exclusión de prueba fundada en la lealtad entre abogados. Es decir, no contaminar dos instituciones que tienen fines diversos. De la misma forma y haciéndose cargo de esta realidad, se dejó en claro que existe la facultad de compartir esa información con el cliente, contenida dentro del pacto de confidencialidad entre sus abogados, sin perjuicio de que el cliente pueda autorizarlo a negociar sin ningún deber de comunicación hacia él, lo cual quedaría entregado a la normas de deberes fiduciarios aprobadas por el Consejo. ${ }^{40}$

El Consejo no alcanzó a discutir estas reglas en una sesión específicamente dedicada al efecto. Ellas fueron adoptadas por la Comisión Revisora en su trabajo de redacción final del nuevo Código durante los meses de enero y febrero de 2011, y en tal calidad sometidas a la aprobación del Consejo en abril de 2011.

$\mathrm{El}$ art. 110 establece en su primera oración el principio general sobre deber de confidencialidad entre abogados de contrapartes: sólo debe confidencialidad el abogado que expresamente consiente en ello. Este es un cambio radical: la ética profesional ya no reconoce heterónomamente "confidencias" entre abogados de contrapartes, sino que hace de la confidencialidad un deber cuya génesis está subordinada al ejercicio de la autonomía de cada abogado.

El art. 111 establece una limitación al deber de confidencialidad para con el abogado de la contraparte. Aun bajo confidencialidad expresamente asumida, el abogado puede compartir la información confidencial con el cliente en cuya consideración esa información le fue revelada. Esta regla resuelve una colisión de deberes que el CEP-1948 dejaba sin solución expresa. ${ }^{41}$ La regla clarifica la prioridad del deber fiduciario para con el cliente respecto del deber convencional de confidencialidad para con el abogado de la contraparte. Con todo, la regla genera tres interrogantes:

(i) El estatus ético del aprovechamiento de la información confidencial en beneficio del cliente en cuya consideración ella fue revelada al abogado. Aunque el art. 111 no lo diga expresamente, como lo hacían la regla 6.2 PD y la regla 6.2 propuesta por el Presidente del Colegio, debe entenderse que el aprovechamiento se encuentra éticamente autorizado por un elemental argumento a fortiori.

\footnotetext{
40 Acta $\mathrm{N}^{\circ} 12 / 2010$, p. 6.

41 A menos que se estime que el silencio del CEP-1948 implica el sacrificio de los deberes fiduciarios para con el cliente a la integridad de la profesión. No está de más observar que el canon 37 de la ABA (1928), fuente del CEP-1948, no contemplaba la institución de la confidencialidad entre abogados de contrapartes.
} 
Bascuñán - Deber de confidencialidad y secreto profesional del abogado

(ii) La practicabilidad del acuerdo de confidencialidad entre los abogados, atendido el derecho del cliente a que esa información le sea compartida. Es obvio que la ética profesional no puede alcanzar a los clientes, por lo que no puede extenderles la confidencialidad que se deben sus abogados entre sí. Es obvio, también, que sin que los abogados adopten alguna precaución adicional la confidencialidad debida se hace ilusoria en poder de la contraparte. Es obvio, finalmente, que el abogado no puede por sí solo renunciar válidamente a su facultad de comunicar al cliente la información confidencial: esta autorización expresa la preponderancia del deber ético de informar al cliente y por lo tanto se encuentra establecida en interés del cliente. ${ }^{42}$ En la discusión en el Consejo 20092011 y la Comisión de Ética pueden advertirse dos medidas. Una es la celebración de un contrato de confidencialidad por el cliente del abogado que recibe la información confidencial. Otra es su renuncia al derecho a ser informado. La primera medida no presenta problema alguno desde el punto de vista de la ética profesional, pero no es de fácil operatividad. La segunda medida es operativa, pero presenta dos problemas éticos. El primero, si es válida esa renuncia. El segundo, asumiendo su validez, cual sea el estatus consecuente del aprovechamiento de la información en beneficio del cliente. ${ }^{43}$

(iii) El estatus de los deberes fiduciarios del abogado para con sus demás clientes. Es claro que el abogado no tiene la facultad de compartir con ellos la información confidencial: así lo establece expresamente el art. 111 y lo confirma el examen de los trabajos preparatorios. De esto no se sigue, sin embargo, la prohibición de aprovechamiento. El mismo argumento a fortiori utilizado para extender la autorización (de la información al aprovechamiento) demuestra que aplicarlo para extender la prohibición seria incurrir en una falacia.

Pese a la diferencia entre la confidencialidad debida al cliente y la confidencialidad debida al abogado de la contraparte, que el CEP-2011 tan nítidamente expresa, no puede negarse que existe una similitud entre el abogado de la contraparte que comunica información bajo confidencialidad expresamente aceptada y el cliente potencial: el abogado que recibe la información debe a ambos confidencialidad pero con ninguno de ellos tiene una relación fiduciaria. Por tal razón, lo dicho a propósito del art. 49 en relación con la información confidencial

\footnotetext{
42 En este punto, la propuesta del Presidente del Colegio era manifiestamente contradictoria con la consideración del interés fiduciario del cliente como interés preponderante. El grupo de trabajo sobre integridad en el trato entre abogados la suprimió bajo la siguiente consideración: "Se eliminó el párrafo que prohibía revelar la información al cliente si se ha convenido expresamente entre los abogados que no le será comunicada, por formar parte del deber de informar contenido en las reglas sobre deberes fiduciarios, sin perjuicio de no quedar prohibida la posibilidad de pactar esa reserva en caso que el cliente lo autorice, lo cual se aviene con las reglas sobre instrucciones del cliente de la misma regulación" (PITA, p. 12, nota 8).

${ }^{43}$ En este punto, la propuesta del Presidente del Colegio era más completa, aunque la exigencia de proporcionalidad y adecuación al fin no expresa con suficiente precisión el margen de legítimo aprovechamiento.
} 
dada por un cliente potencial debería ser aplicable también a las cuestiones (ii) y (iii) planteadas por el art. 111.

El art. 110 establece en su segunda oración una regla especial, consistente en la prohibición de hacer valer en juicio "los documentos y demás antecedentes que se hayan obtenido del abogado de la contraparte en el curso de la negociación de avenimientos, conciliaciones y transacciones frustradas". La redacción del art. 110 presenta esta regla como una excepción al principio general establecido en su primera oración. Pero eso es un error. El tratamiento de la segunda oración como excepción al principio establecido en la primera oración se explica por la contraposición entre obligatoriedad autónoma vs. obligatoriedad heterónoma. Pero son normas de comportamiento cuyo contenido es distinto. La segunda oración no establece un deber de confidencialidad que no requiera aceptación expresa, sino una prohibición de producción de prueba que no está condicionada a su libre asunción por el abogado. El término "juicio" debe ser entendido en sentido amplio, como comprensivo de cualquier procedimiento adjudicatorio de derechos controvertidos por las partes. La prohibición de la prueba documental debe entenderse como comprensiva de la prueba testimonial referida a la existencia y contenido de los documentos. Finalmente, es claro que la prohibición no tiene por destinatario exclusivo al abogado receptor de los documentos y antecedentes sino a cualquier abogado. El uso de la forma verbal reflexiva como pasivo -"no podrán hacerse valer"- es expresivo del carácter impersonal y general de la prohibición. El abogado que reemplaza al abogado que representó al cliente en la negociación fallida tampoco puede hacer valer esos documentos o antecedentes. 